\title{
LES OCUPACIONS PREHISTÒRIQUES DE CUEVA DE LA DiABla (AYORA, VALÈNCIA)
}

La realització del parc eòlic de la Solana (Ayora) propicià una sèrie de sondejos arqueològics a Cueva de la Diabla que permeteren identificar un nivell arqueològic prehistòric del Calcolític campaniforme-Bronze antic. L'estudi de la totalitat de les restes ens ha permès interpretar-les com a conseqüència d'ocupacions estacionals de la cova, no documentant cap evidencia d'enterraments humans. La cacera d'animals salvatges que viuen en un medi escassament antropitzat també ha quedat constatada.

Paraules clau: Cueva de la Diabla, Valle de Ayora, prehistòria, ocupacions estacionals.

\section{Prehistoric ocupations at La Diabla Cave (Ayora, València)}

The construction of the wind park La Solana (Ayora) led to a series of archaeological sondages at Cueva de la Diabla. These works uncovered a prehistoric occupation layer dated to the Bell Beaker-Early Bronze Age periods. The study of the recovered materials suggests that the occupation of the cave was seasonal. No evidence of human burials has been documented. Wild animal hunting was taking place in an environment with hardly any signs of anthropization.

Key words: Cueva de la Diabla, Ayora Valley, prehistory, seasonal occupation.

Durant la realització dels estudis d'impacte ambiental per a la construcció del parc eòlic de La Solana (Ayora, València), es van detectar diferents punts d'interès patrimonial en l'àmbit d'afecció. Un d'aquests punts és el de Cueva de la Diabla, que es troba als voltants del parc. Per aquesta raó va ser objecte d'una intervenció arqueològica.

Aquesta es realitzà baix la direcció de Carlos Verdasco i Pablo García. La primera de les campanyes, entre novembre de 2007 i gener de 2008, consistí en la realització de tres sondejos. El resultat d'un d'aquests provocà una segona intervenció en març i abril de 2008 per tal de contextualitzar les restes de forma més correcta. En aquesta publicació es presenten els treballs realitzats en aquestes campanyes.

\section{CUEVA DE LA DIABLA}

El jaciment està ubicat al límit NE del terme municipal d'Ayora (30T 682033/4320646), en les immediacions de la "Cañada Real de San Benito" (segons la cartografia temàtica forestal de la Conselleria de Medi Ambient de la Generalitat Valenciana) o "Camino de las Casas del Hondo del Alubis" (mapa 768 del Instituto Geológico Minero de 1956).

Es tracta d'un assagador que travessa el Alto del Buitre i la partida de La Solana fins l'encreuament dels termes municipals d'Ayora, Bicorp, Quesa i Enguera, junt a l'actual parc eòlic de La Solana (fig. 1). La cova es troba prop de les cases que li donen nom al parc, actualment en estat de runa. 


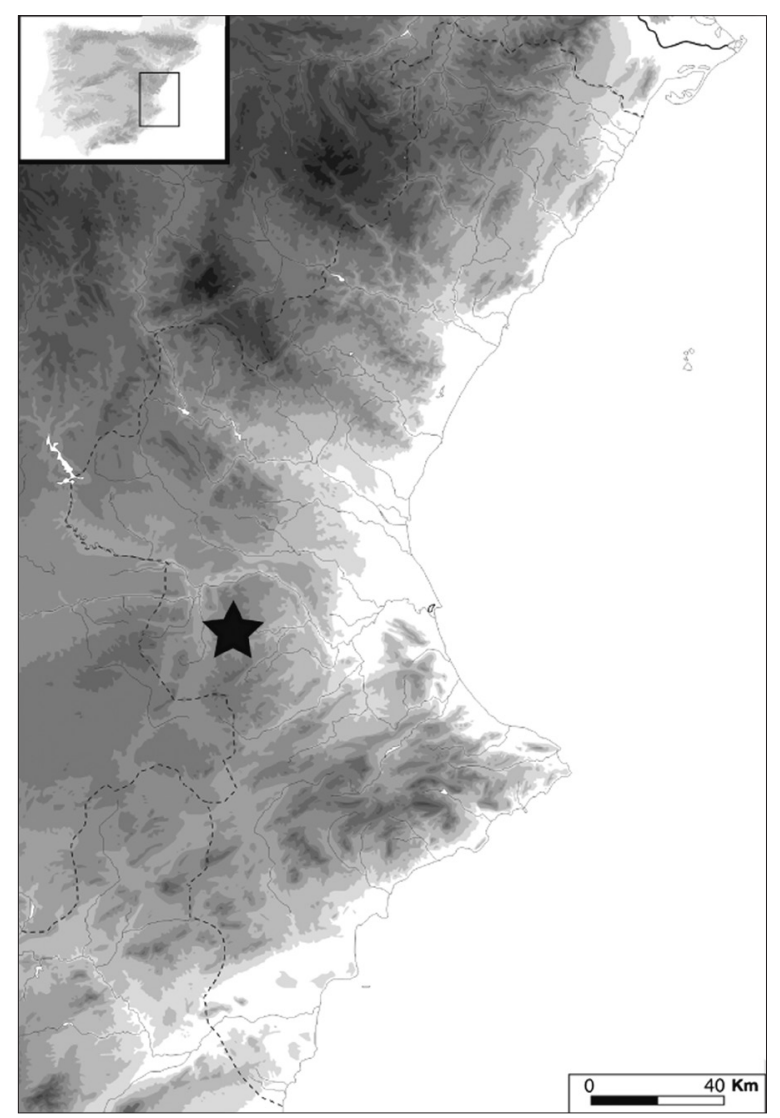

Fig. 1. Ubicació geogràfica de Cueva de la Diabla.

Presenta una ampla boca d'entrada de morfologia circular (fig. 2), amb un mur fet de pedra en sec. Aquesta dóna pas a una ampla galeria adaptada a la presència d'un diàclasi que la creua i que produeix l'erosió diferencial als dos costats, marcada per una evident morfologia hídrica que provoca que la potència del sediment que la rebleix siga prou més elevada a l'interior de la cavitat. És per aquest motiu que la morfologia real és diferent en la part interna (fig. 3). La cova presenta una secció transversal circular, allargada i estreta, de tendència angosta al seu interior. La longitud de la galeria s'aproxima als $15 \mathrm{~m}$ i continua a través d'una gatera parcialment reblida. L'amplària màxima es de 3,8 m i la mínima d'1,4 m. Destaca la presència de colades estalagmítiques, que afloren de forma més intensa al fons de la galeria. Darrere d'aquestes s'obri una xemeneia de desenvolupament zenital que comunica amb l'exterior, d'1,5 x 0,5 m aproximadament, amb una diferència de cota de $4 \mathrm{~m}$. Aquesta xemeneia comunica amb una petita galeria superior amb obertura a l'exterior a través de la qual s'ha produït bona part de l'aportació sedimentaria.

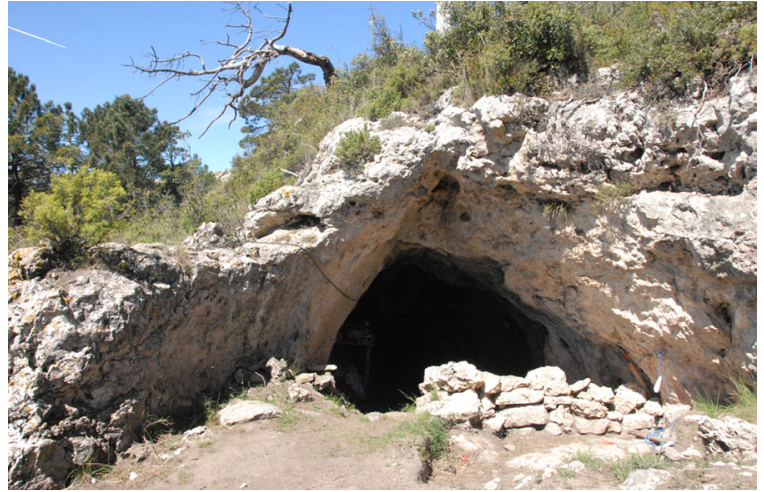

Fig. 2. Boca d'entrada de la cavitat.

Les dades historiogràfiques que tenim són confuses. La millor referència la trobem a l'inventari de jaciments arqueològics de la Direcció General de Patrimoni de la Generalitat Valenciana. En la fitxa existent sobre la cova, tant les coordenades com la descripció del lloc són coincidents amb les nostres. Està inventariada pels col·legues Reyes Borredà i Evarist Aznar, que destaquen la troballa d'una punta de fletxa de sílex al seu interior.

Les referències bibliogràfiques que hem rastrejat sobre el jaciment remeten a les actuacions que el Grupo Arqueológico de La Valle realitzà a la comarca als anys 80 del segle passat, en ocasions amb la col-laboració de J. Aparico Pérez (Aparicio et al. 1983: 379-382). Una d'aquestes actuacions es centrà en l'interessant poblat del Puntal del Olmo Seco (també conegut com El Barco), on es documentà una cabanya de morfologia circular associada a ceràmiques realitzades a mà i restes de sílex entre les que destaquen puntes de fletxa. En la publicació d'aquesta notícia sobre la intervenció en el poblat (Aparicio et al. 1983), es fa referència a la visita realitzada a unes pintures rupestres en una balma situada al paratge de la Diabla. A partir de les dades però, entenem que aquestes pintures es troben als voltants del puntal, allunyades de la cova en què hem realitzat l'actuació. En aquest mateix sentit, J.V. Poveda (2001: 38-39) ubica la cova junt al Puntal del Olmo Seco en relació amb les fitxes de jaciments del Museu de Prehistòria de València, fitxa que no proporciona dades geogràfiques de la mateixa, per la qual cosa no sabem si es tracta d'una errata que es ve repetint per la descripció que es fa de la visita als anys 80, o si ens trobem davant de dos emplaçaments diferents que coincideixen en la seua nomenclatura.

Hem respectat el topònim que apareix a la base de dades de jaciments de la Generalitat Valenciana, doncs no hi ha dubte que estem davant la mateixa cova. 


\section{LA INTERVENCIÓ ARQUEOLÒGICA}

La metodologia emprada ha estat mixta. Hem utilitzat alhora un mètode adaptat a l'excavació d'una cova (capes de $5 \mathrm{~cm}$ ) amb un altres principis aplicats en jaciments a l'aire lliure (Harris 1989), assignant un número d'unitat a cada estrat o estructura diferenciada, siga d'origen natural o antròpic. La nomenclatura utilitzada per enumerar les diferents unitats queda relacionada amb el sondeig en què apareixen: les unitats 1000 al sondeig 1, les 2000 al 2 i les 3000 al 3.

Primerament es va realitzar un quadriculat de la superfície de la cova amb dos eixos X-Y, un representat amb números i l'altre amb lletres (fig. 3). Cal destacar que a l'última fase d'excavació del sondeig 3 es va decidir emprar un caragol manual utilitzat normalment per a prendre mostres, com a conseqüència de la seua fondària i risc de despreniments al tall.

La intervenció ha consistit en la realització de tres sondejos i la neteja d'altres dos, més petits i de morfologia quadrangular que associem a actuacions clandestines. Una vegada finalitzats els treballs, els sondejos foren tapats amb geotèxtil i coberts amb el sediment que havíem extret de la mateixa cova.

El sondeig 1, de $2 \times 2 \mathrm{~m}$, té una fondària de 45-30 $\mathrm{cm}$, i es troba a la boca d'entrada. En ell es van diferenciar tres estrats: un primer de sediment obscur format majoritàriament per llims, amb nombroses arrels i restes ceràmiques contemporànies; un segon més sorrenc de color marró clar, estèril arqueològicament; i finalment, un tercer estrat semblant a l'anterior que es recolza directament en la roca, que tampoc proporcionà materials arqueològics.

El sondeig 2, de 2 × 3 m i una fondària propera als 50 $\mathrm{cm}$, fou ubicat a l'entrada de la cova i proporcionà una seqüència sedimentològica semblant a l'anterior, no documentant-se restes arqueològiques prehistòriques. A l'extrem $\mathrm{O}$ del quadre D-5 es van localitzar restes de sediment sotmès a l'acció del foc, amb una potència màxima de $18 \mathrm{~cm}$, diferenciant-se una primera capa de cendres compactades amb coloració blanca i una segona situada sobre aquesta, també cendrosa, de color gris i amb carbons. El sondeig 2 sols proporcionà material arqueològic de cronologia contemporània.

El sondeig 3 va ser ubicat al centre de la cova. Les seues mesures inicials eren d'1,5 x 2 m (quadres D10/D11 i la meitat dels $\mathrm{C} 10 / \mathrm{C} 11$ ). Però per motius de seguretat $\mathrm{i}$ de capacitat operativa sols van ser excavats totalment els quadres D11/C11, i parcialment l'E11. La seua excavació permeté diferenciar quatre grans nivells estratigràfics (fig. 4 i 5):

Superficial. Capes 1 a 3. El sediment és poc compacte i presenta materials arqueològics barrejats de diferent cronologia. Té una potencia de $27 \mathrm{~cm}$.

Nivell I. Arranca a la capa 4 i finalitza a la 14. Es correspon amb un sediment sorrenc i llimós de tonalitats marrons i grises poc compactat amb abundant matèria orgànica i clasts. Presenta materials arqueològics d'època moderna, ibèrica i prehistòrica. Té una potència de $53 \mathrm{~cm}$.

Nivell II. Capes 15 a 22. Es correspon amb l'únic nivell arqueològic homogeni diferenciat. Tot el material és
Fig. 3. Planta i seccions de Cueva de la Diabla. Ubicació dels sondejos realitzats en 2008 i dels forats de clandestins als que anomenen Sondeig Antic 1 i 2.

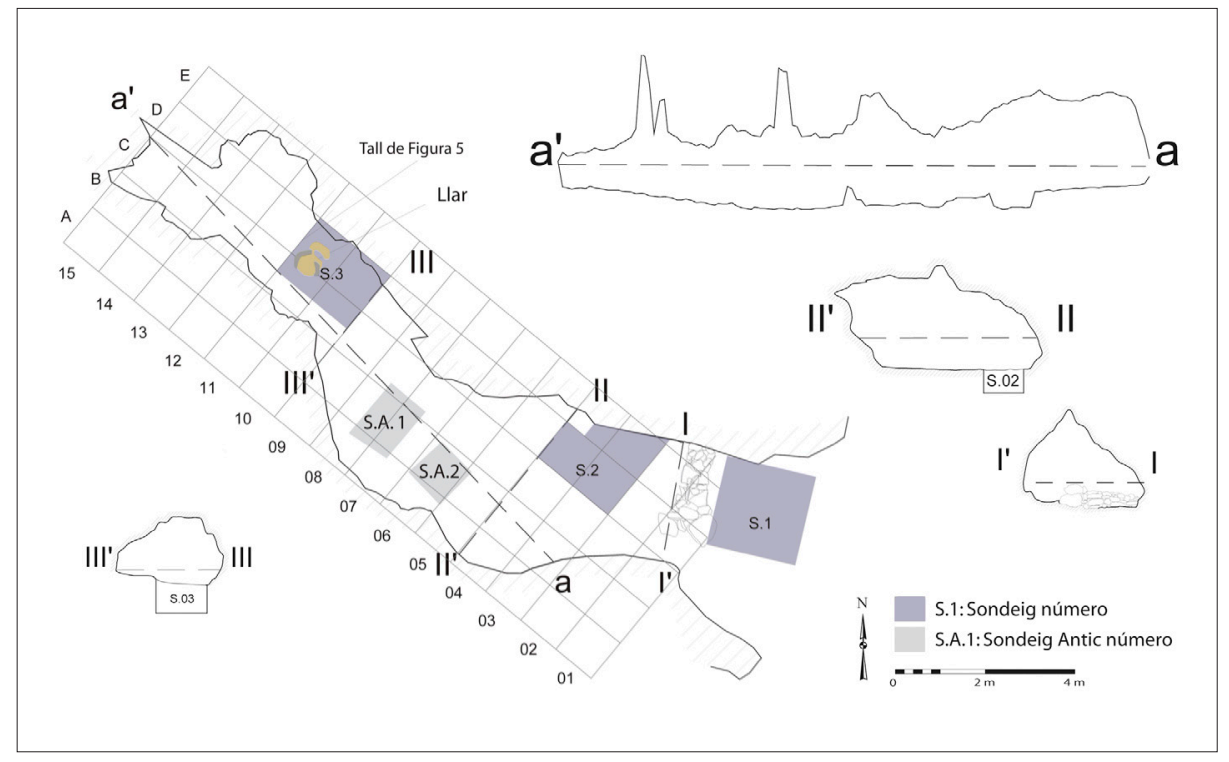


Pablo García Borja, Yolanda Carrión Marco, José Enrique López Peris, Juan Vicente Morales Pérez, Salvador Pardo Gordó, Felip Pérez i Ferrer, Guillem Pérez Jordà, Dídac Roman Monroig, Pablo Sañudo Die, Carlos Verdasco Cebrián

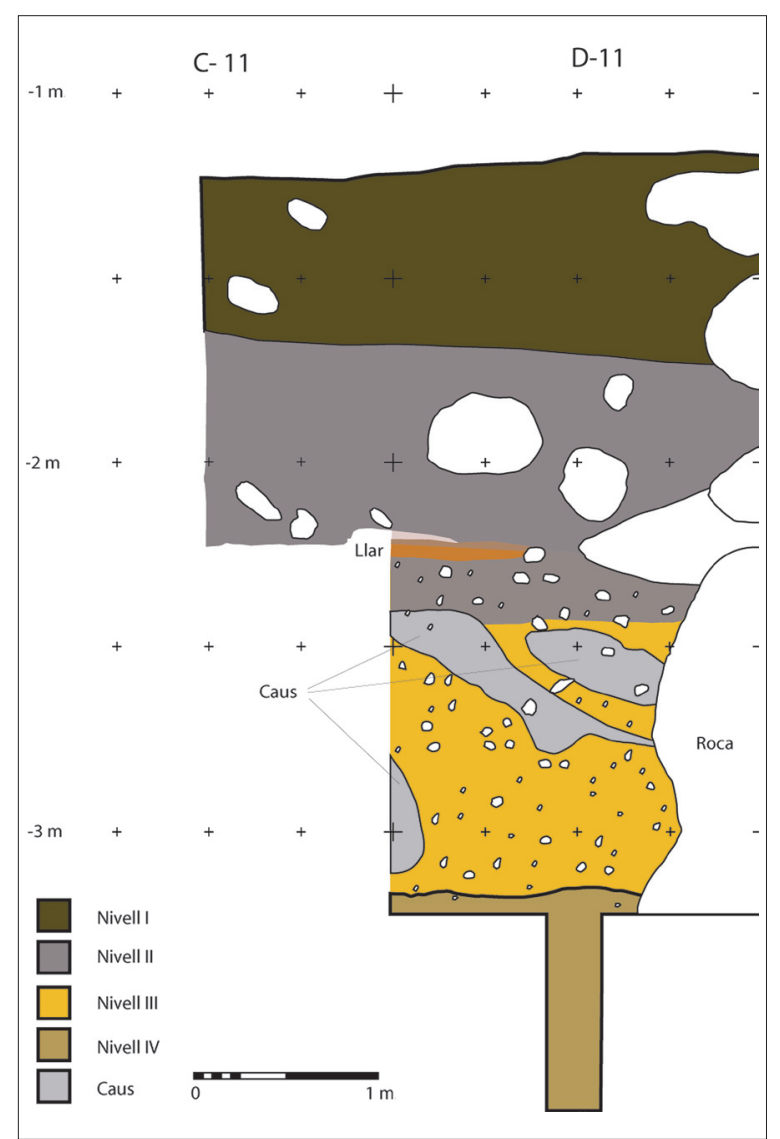

Fig. 4. Tall frontal del sondeig 3 .

de cronologia prehistòrica. Està format per un sediment similar al que documentem al nivell anterior, també caracteritzat per una composició llimosa i arenosa porosa amb presència de graves i aportacions puntuals de blocs mitjans i grans. És un dipòsit parcialment remogut com a consequiència de: les diferents ocupacions, dels propis processos de sedimentació natural i de la gran quantitat de caus existents (UUEE 3004, 3005, 3006, 3007, 3008 i 3009). Tot i això, el material arqueològic documentat és prou homogeni. Disposem d'una datació realitzada sobre un gra de blat que aparegué en la capa 21-22, amb el resultat de $3630 \pm 30$ BP (Beta-295771). La calibració a $2 \sigma$ amb el programa Calib 6.0, IntCal09 (Reimer et al. 2009) proporciona el següent rang cronològic: 2127-1903 BC.

La troballa més interessant realitzada al sondeig 3 és la identificació de part d'una llar que comença a una cota de $-2,17 \mathrm{~m}$ i finalitza a $-2,27 \mathrm{~m}$ (capes 17,18 i 19), $20 \mathrm{~cm}$ sobre el Nivell III. Té unes dimensions aproximades de 0,48 x 0,64 m (fig. 6). En la part superior conservava restes de cendra blanca, que no conformava una estructuració

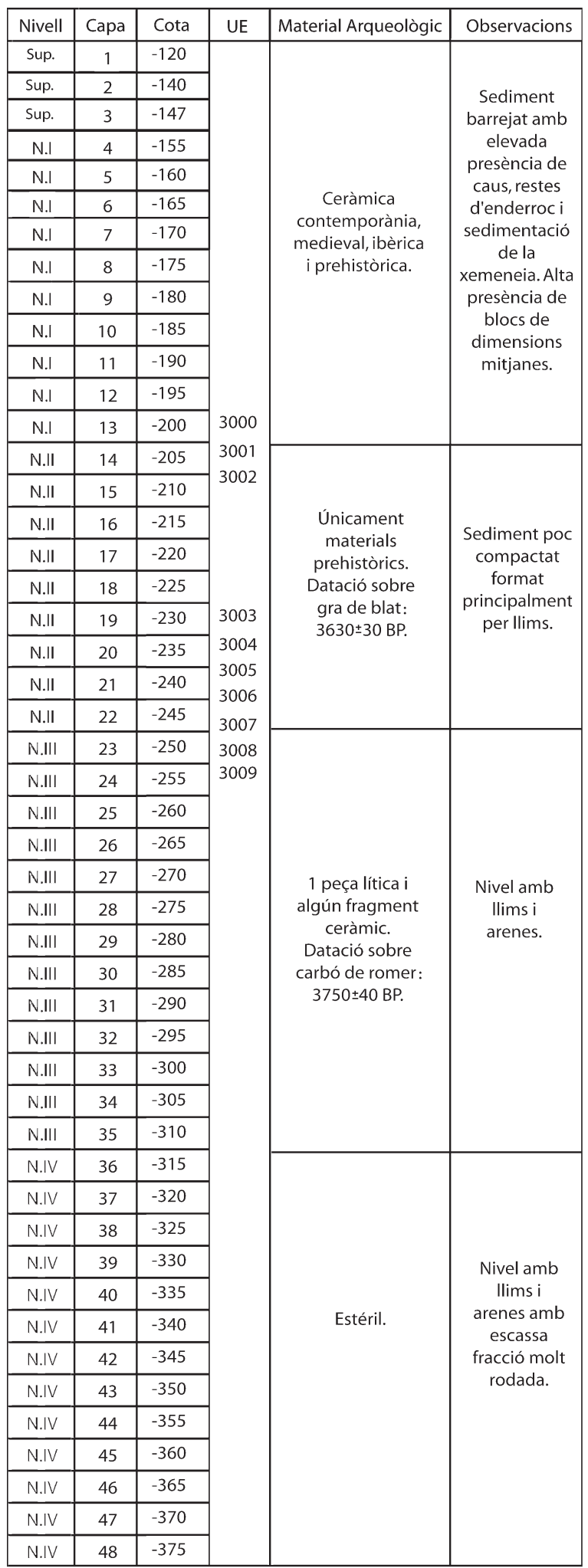

Fig. 5. Relació de capes i nivells arqueològics al sondeig 3. 


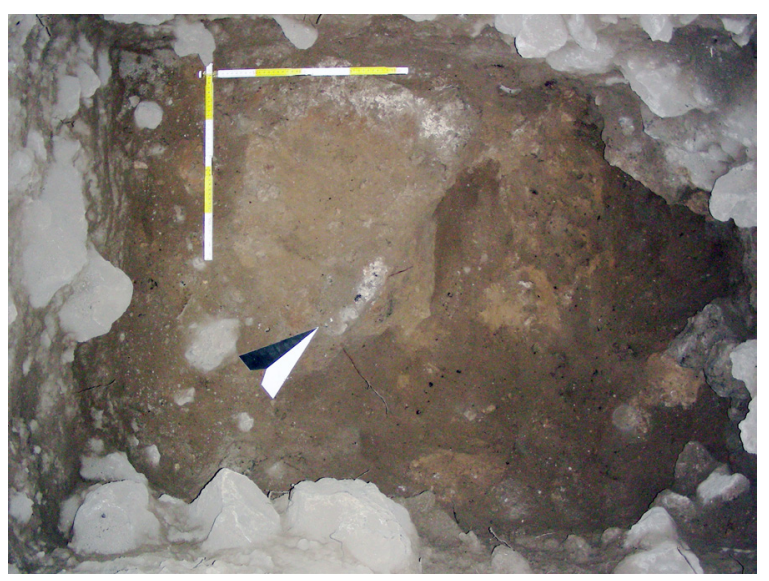

Fig. 6. Llar en C/D-11.

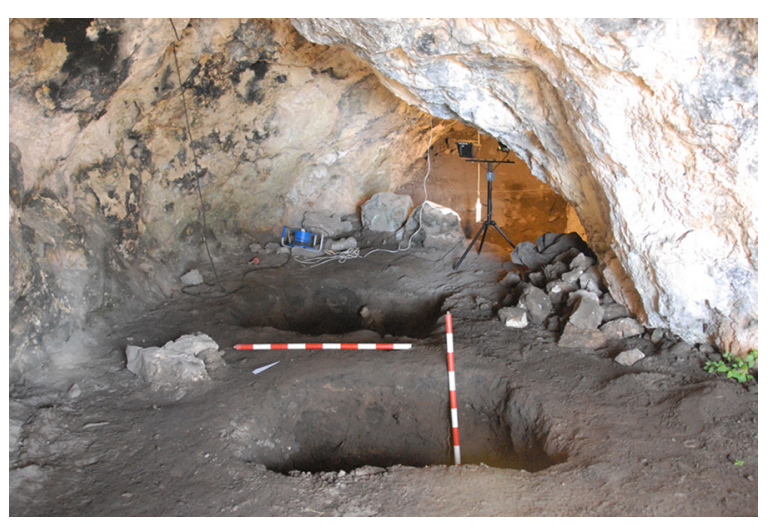

Fig. 7. Neteja dels Sondejos Antics 1 i 2. Al fons el sondeig 3.

homogènia sinó més aviat blocs dispersos i desarticulats. $\mathrm{Al}$ voltant, barrejada amb aquestes, també es documenten minúscules restes d'argila cuita. Es diferenciaren tres unitats, 3001 (cendres) 3002 (argila al seu voltant, barrejada amb cendres) i 3003, que és la superfície endurida sobre la que apareixen les altres dues unitats. L'excavació d'aquestes tres unitats no permeté documentar material arqueològic.

Sota el fogar, les capes 20-22, encara que enquadrades en el Nivell II, cal admetre que presenten algunes característiques del següent estrat, com és la major presència percentual de sorres amb els llims i clasts de fracció més petita.

Nivell III. Capes 23 a 35. Es tracta d'un nivell que també es documenta en la base dels altres sondejos. Presenta textura porosa formada per llims i sorres amb abundants carbonats de coloració taronja i clasts angulosos de grandària petita i mitjana. Té un important cabussament en direcció N. Encara que en aquest nivell apareixen algunes restes arqueològiques, la seua presència és molt escassa i ha estat interpretada en relació amb el gran nombre de caus documentats i amb les alteracions que provoca en el sediment l'activitat d'animals $\mathrm{i}$ persones. És per aquest motiu que la seua formació es va interpretar en un primer moment com natural. No obstant, destaca la presència d'un bon nombre de carbons. Aquestos van ser recollits una vegada netejats els caus. D'aquest nivell disposem d'una datació realitzada sobre un fragment carbonitzat de romer aparegut a la capa 28. El resultat n'és $3750 \pm 40$ BP (Beta-295149). La calibració a $2 \sigma$ amb el programa Calib 6.0, IntCal09 (Reimer et al. 2009) proporciona el següent rang cronològic: 2286-2035 BC.

Nivell IV. Capa 36 a 48. En aquest nivell no es detectà cap resta arqueològica. Es un sediment de textura 1limosa i escassament sorrenca amb coloració taronja similar a la del Nivell III, però amb un major component de llims. Part d'aquest nivell fou excavat amb un aparell per prendre mostres fins una cota de $-3,75 \mathrm{~m}$.

L'actuació arqueològica a la cova finalitzà amb la neteja de dos sondejos antics situats entre el 2 i el 3 (fig. 7), dels que no hem pogut trobar cap tipus de referència $o$ documentació bibliogràfica. Les dimensions són d' 1 x 1 m i 1 x 1,50 m respectivament.

\section{ELS MATERIALS PREHISTÒRICS}

En els pròxims apartats anem a presentar les restes prehistòriques, centrant-nos en el Nivell II del sondeig 3. Assenyalar que als sondejos 1 i 2 es recuperaren materials de cronologia moderna i contemporània, entre els que cal destacar la presència de teules que relacionem amb algun tipus de sostre a l'entrada de la cova. Al Nivell I del sondeig 3, també es documenten materials contemporanis (fig. 8,1) i moderns (fig. 8,2), entre ells una moneda (4 Maravedís d'Isabel II) a la capa 1 (fig. $8,9)$, que proporciona una data en la seua llegenda de 1842. També hem documentat algunes restes de cronologia ibèrica (fig. 8,3,4,8,10 i 11), destacant dues vores de dolls i altra d'una olla de cuina. Aquests materials són minoritaris i apareixen barrejats amb altres de cronologia prehistòrica, entre els quals hi ha un fragment ceràmic incís realitzat a mà (fig. 8,6), altre també realitzat a mà amb cordó (fig. 8,5) i un fragment distal de punxó sobre fragment longitudinal de la diàfisi d'un mesomamífer (fig. 8,7). 


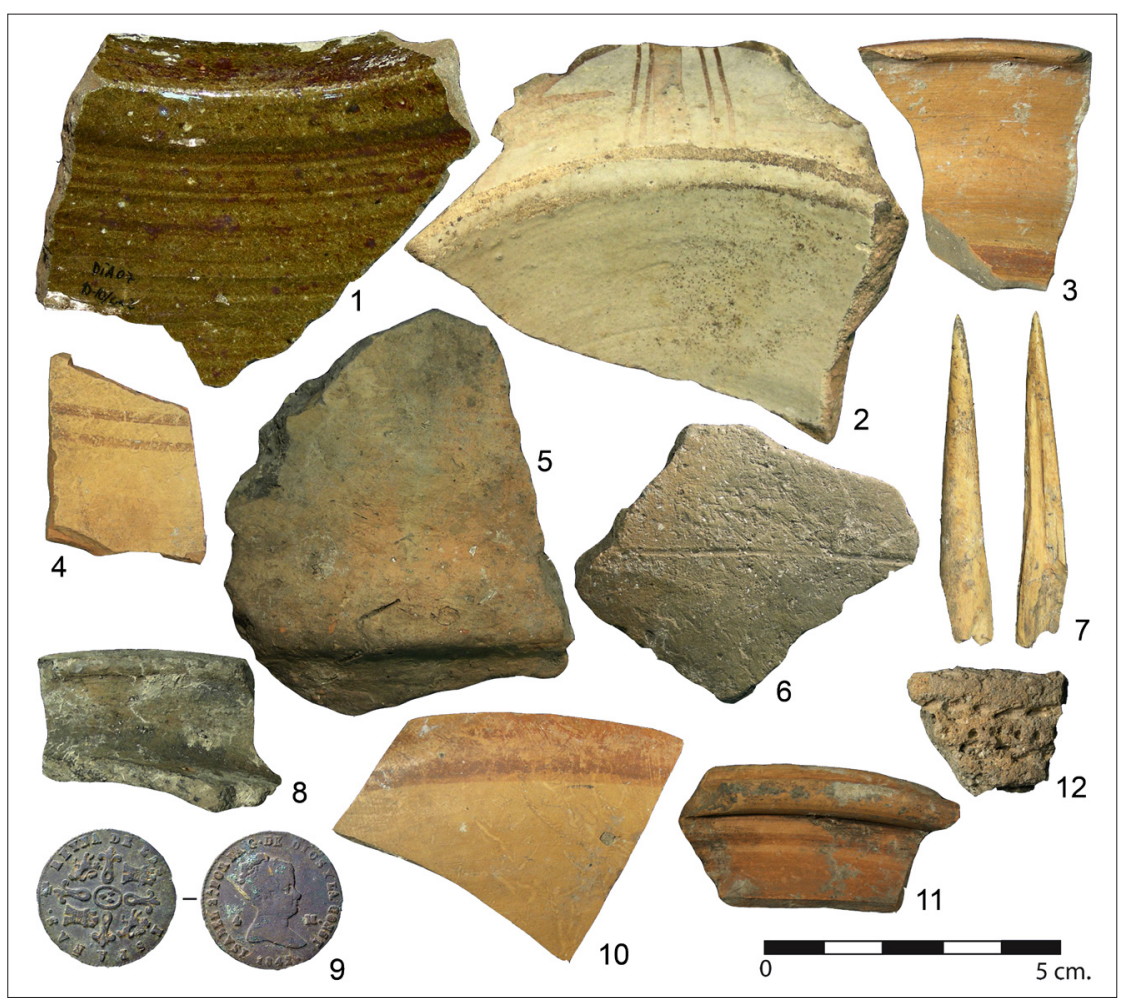

Fig. 8. Materials arqueològics apareguts al Nivell I del sondeig 3 (1-11) i Sondeig Antic 2 (12).

\section{LA CERÀMICA A MÀ}

El mètode d'anàlisi tipològic que hem aplicat està basat en la proposta establerta per al Neolític al País Valencià (Bernabeu 1989; Bernabeu et al. 2009), recentment ampliada (García Borja et al . 2011). Seguint aquesta proposta, l'estudi del material arqueològic es divideix en dues fases: l'estudi dels fragments i el dels vasos.

\section{ESTUDI DELS FRAGMENTS}

S'han analitzat un total de 558. Aquests han estat recuperats al sondeig $3 \mathrm{i}$ a la neteja dels dos sondejos antics existents. D'aquests 558, 59 estan realitzats a torn i la resta a mà. Com ja hem assenyalat, la majoria dels 54 fragments a torn són de cronologia moderna, documentant també algun d'època ibèrica.

Dels 499 fragments fets a mà, huit aparegueren en la neteja dels sondejos antics i la resta al sondeig 3 (fig. 9). Únicament 72 d'ells proporcionen informació de la forma, llavi, vora, base, ansa i/o decoració. Per nivells (fig. 9), a l'estrat superficial hem documentat un total de 107 fragments, dels quals 21 proporcionen informació de la seua forma. Del Nivell I s'han recuperat 293 fragments ceràmics a mà, dels quals 37 proporcionen informació morfològica.
Al Nivell II, 81 fragments a mà i cap a torn, 10 amb informació morfològica; al Nivell III s'han recuperat 10 fragments a mà, tots ells informes; finalment, al Nivell IV no s'ha documentat cap fragment ceràmic. La desigual distribució en nombre de fragments ve condicionada tant per la major potència del Nivell I com per la superfície excavada, que en el cas del Nivell I és notablement superior.

S'han inventariat 62 fragments fets a mà que presenten llavi (fig. 9), documentant la presència dels tipus: arrodonits (L1. 1), pla (L1.2), bisellats arrodonits (L1. 3.2), engreixats a la part interna (L1.4.2), engreixat doble arrodonit (L1. 6.2) i amb vora interna destacada (L1. 7.1). Els arrodonits són els més abundants amb 54 exemplars, els altres apareixen de forma més puntual.

De les 45 vores inventariades (fig. 9), destaca l'elevada presència de les no diferenciades. La majoria de les vores diferenciades són lleugerament exvasades. Hem inventariat tres vores com a recta/re-entrant.

$\mathrm{S}$ 'han recuperat huit fragments ceràmics de bases (fig. 10), identificades en la seua totalitat com a bases convexes de perfil senzill o com a bases aplanades sense taló.

Pel que fa a les anses, només apareixen dues variables (fig. 10): un fragment amb un petit cordó i dos fragments amb mugró. 


\begin{tabular}{|l|ccc|c|c|c|c|c|c|c|c|c|c|c|c|}
\cline { 2 - 16 } \multicolumn{1}{c|}{} & Fragments & Torn & Mà & $\%$ & Forma & $\%$ & Ll.1 & L1.2 & L1.32 & L1.42 & L1.62 & L1.71 & Vora 0 & Vora 1 & Vora 2 \\
\hline Superficial & 143 & 36 & 107 & 21 & 21 & 29 & 17 & 1 & 1 & 0 & 0 & 1 & 8 & 2 & 5 \\
\hline Nivell I & 314 & 21 & 293 & 59 & 37 & 51 & 25 & 0 & 1 & 1 & 1 & 1 & 13 & 1 & 9 \\
\hline Nivell II & 81 & 0 & 81 & 16 & 10 & 14 & 9 & 0 & 1 & 0 & 0 & 0 & 3 & 0 & 2 \\
\hline Nivell III & 10 & 0 & 10 & 2 & 0 & 0 & 0 & 0 & 0 & 0 & 0 & 0 & 0 & 0 & 0 \\
\hline Nivell IV & 0 & 0 & 0 & 0 & 0 & 0 & 0 & 0 & 0 & 0 & 0 & 0 & 0 & 0 & 0 \\
\hline Sond. Ant. 1 & 4 & 1 & 3 & 0,6 & 2 & 2,8 & 2 & 0 & 0 & 0 & 0 & 0 & 1 & 0 & 0 \\
\hline Sond. Ant. 2 & 6 & 1 & 5 & 1 & 2 & 2,8 & 1 & 0 & 0 & 0 & 0 & 0 & 1 & 0 & 0 \\
\hline Total & 558 & 59 & 499 & 0 & 72 & 100 & 54 & 1 & 3 & 1 & 1 & 2 & 26 & 3 & 16 \\
\hline
\end{tabular}

Fig. 9. Relació de fragments realitzats a torn i a mà que presenten forma. Fragments amb llavi diferenciat: Llavi arrodonit (L1.1), pla (L1.2), bisellat arrodonit (L1. 32), engreixat pla (Ll. 42), engreixat doble arrodonit (Ll. 62) amb revora (Ll. 71). Fragments amb vora: no diferenciada (vora 0 ), vora recta-entrant (vora 1 ) i vora exvasada (vora 2 ).

\begin{tabular}{|l|c|c|c|c|c|c|c|c|c|}
\cline { 2 - 10 } \multicolumn{1}{c|}{} & Base 1 & Base 41 & Ansa 1 & Ansa 3 & Dec 21 & Dec 431 & Dec 432 & Dec 5 & Dec 10.1 \\
\hline Superficial & 1 & 1 & 0 & 2 & 0 & 0 & 0 & 0 & 0 \\
\hline Nivell I & 2 & 4 & 1 & 0 & 1 & 0 & 0 & 1 & 0 \\
\hline Nivell II & 0 & 0 & 0 & 0 & 0 & 0 & 0 & 0 & 1 \\
\hline Nivell III & 0 & 0 & 0 & 0 & 0 & 0 & 0 & 0 & 0 \\
\hline Nivell IV & 0 & 0 & 0 & 0 & 0 & 0 & 0 & 0 & 0 \\
\hline Sond. Ant. 1 & 0 & 0 & 0 & 0 & 0 & 0 & 0 & 0 & 0 \\
\hline Sond. Ant. 2 & 0 & 0 & 0 & 0 & 0 & 1 & 1 & 0 & 0 \\
\hline Total & 3 & 5 & 1 & 2 & 1 & 1 & 1 & 1 & 1 \\
\hline
\end{tabular}

Fig. 10. Fragments de base convexa (base 1) i aplanada (base 41). Elements de prensió diferenciats: mugrons (Ansa 3) i cordons (Ansa 1). Tècniques decorades identificades: Cordons llisos (Dec 21), impressions de punxó en posició horitzontal (Dec 431), impressions de punxó en posició obliqua (Dec 432), incisions (Dec 5) i impressions al llavi (Dec 10.1).

Únicament quatre fragments presenten decoració, documentant-se cinc tècniques: la impressió al llavi, el cordó llis, la incisió i la impressió amb punxó rom en posició vertical i obliqua. En un d'aquestos fragments decorats (aparegué en la neteja d'un dels sondejos antics) aquestes dues tècniques apareixen combinades (fig. 8,12).

\section{ESTUDI DELS VASOS}

Processat tot el material ceràmic, hem pogut identificar un nombre mínim de 23 individus. Hem d'assenyalar que en aquest recompte hem inclòs dues unitats aparegudes al sondeig antic 2 .

Pel que fa a la tipologia del conjunt de vasos diferenciats (fig. 11), dos han quedat enquadrats en la Classe F o indeterminada (fig. 12). Dins dels vasos que poden classificar-se, els pertanyents a la Classe A són els més nombrosos amb 12 individus. Són en la majoria d'ocasions escudelles (A.2.I.a) i fonts (A.4.I.a) de perfil senzill i base plana, si bé cal destacar la presència d'un plat (A.1.I) i de tres vasos amb llavi diferenciat, engreixat a la part interna (A.2.I.b) o amb vora interna destacada associada a escudella (A.2.I.f) o a font (A.4.I.f), grups als quals podria incorporar-se el vas 12, encara que finalment l'hem classificat amb llavi arrodonit. Els llavis diferenciats associats a formes simples de Classe A tenen els seus directes paral·lels al Neolític II de la seqüència regional (Bernabeu 1989; Bernabeu i Guitart 1993; Bernabeu i Orozco 1994).

El segon grup de vasos en representació el conformen els vasos de Classe B amb sis individus, entre els que destaca la presència de quatre individus classificats com a Grup 6 tipus II subtipus a (B.6.II.a): bols de perfil senzill i forma oberta amb llavi arrodonit. També s'han classificat dos vasos (2 i 13) com a bols de perfil en $\mathrm{S}$ sense carena (B.8.II.).

Finalment, dos vasos han quedat classificats dintre la Classe C. Un com a olla amb vora lleugerament exvasada (C.13.III.b) i l'altre com a contenidor amb vora diferenciada també lleugerament exvasada (C.14.III.b).

\section{CARACTERITZACIÓ}

De l'estudi dels fragments podem extraure algunes conclusions, basades més en absències que presències: absència d'un conjunt representatiu de ceràmiques decorades mitjançant impressions, incisions, esgrafiat o pentinat; absència quasi total d'anses, de bases planes de taló associades amb vores girades, o de formes carenades $\mathrm{i}$ formatgeres.

Pel que fa a l'apartat de les decoracions, al vas 21, s'han utilitzat dues tècniques, un punxó esmolat en posició horitzontal, i un altre més rom en posició obliqua, 
Pablo García Borja, Yolanda Carrión Marco, José Enrique López Peris, Juan Vicente Morales Pérez, Salvador Pardo Gordó,

Felip Pérez i Ferrer, Guillem Pérez Jordà, Dídac Roman Monroig, Pablo Sañudo Die, Carlos Verdasco Cebrián

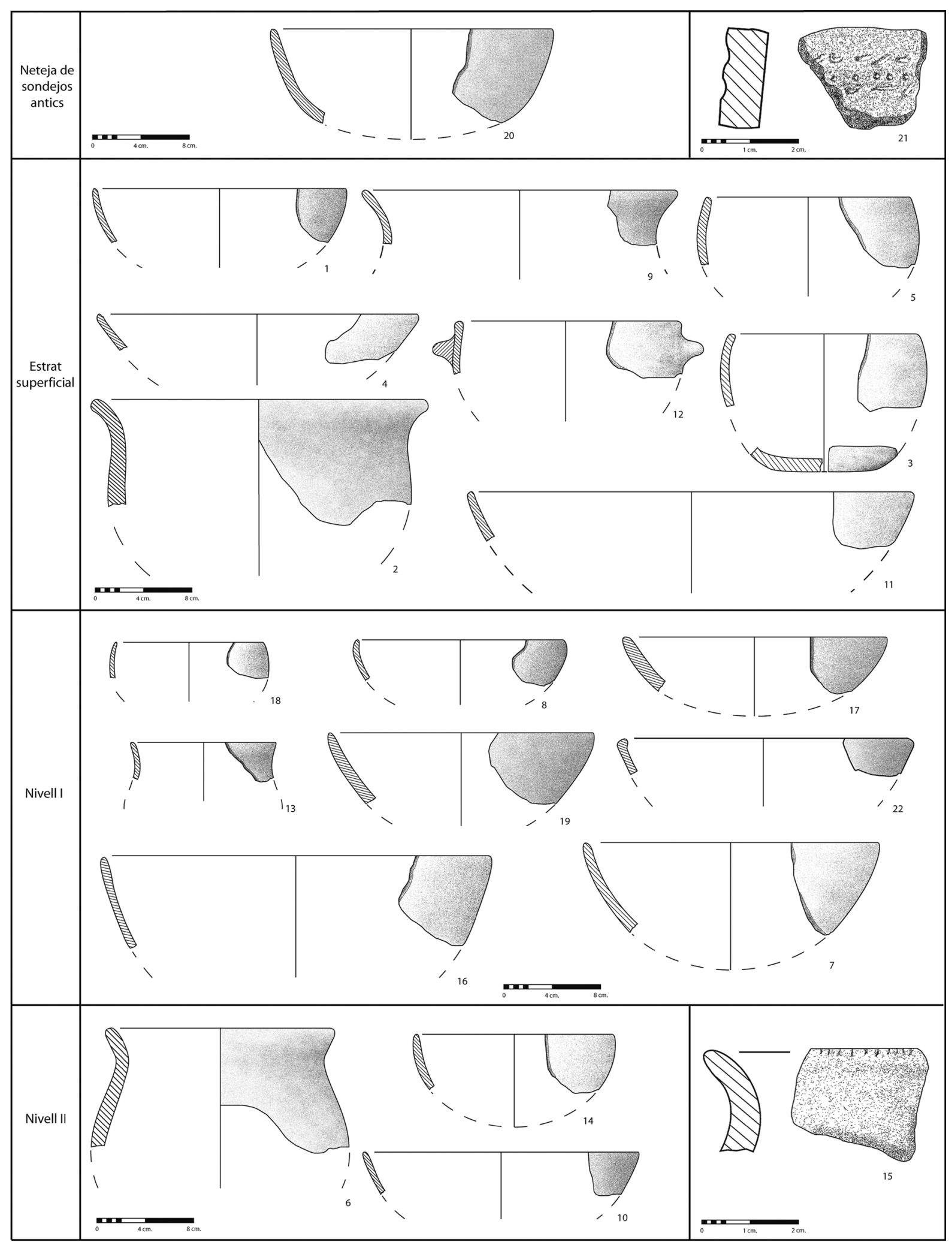

Fig. 11. Perfils dels vasos ceràmics diferenciats. 


\begin{tabular}{|c|c|c|c|c|c|c|c|c|c|c|c|c|c|c|c|c|c|}
\hline Vas & Nivell & Llavi & Vora & Base & Ansa & Dec. 1 & Dec. 2 & $\mathrm{Db}$ & Dm & $\mathrm{H}$ & Classe & Grup & Tipus & Sub.T & Color Extern & Cocció & Gr \\
\hline 1 & SUP & 1 & 0 & 1 & & 0 & & 20 & 20 & 7 & A & 2 & I & a & Beige & Reductora & 1 \\
\hline 2 & SUP & 1 & 2 & & & 0 & & 27 & 27 & & $\mathrm{~B}$ & 8 & II & & Beige & Reductora & 3 \\
\hline 3 & SUP & 1 & 0 & 41 & & 0 & & 15 & 17 & 11 & B & 6 & II & $\mathrm{a}$ & Beige & Reductora & 3 \\
\hline 4 & SUP & 71 & 0 & & & 0 & & 26 & 26 & & A & 4 & $\mathrm{I}$ & $\mathrm{f}$ & Negre & Reductora & 2 \\
\hline 5 & SUP & 1 & 0 & & & 0 & & 16,5 & 18 & 9,5 & B & 6 & II & $\mathrm{a}$ & Negre & Reductora & 2 \\
\hline 6 & II & 1 & 2 & & & 0 & & 18 & 19,5 & 15 & C & 13 & III & b & Negre & Mixta & 3 \\
\hline 7 & $\mathrm{I}$ & 1 & 0 & & & 0 & & 24 & 24 & & A & 2 & $\mathrm{I}$ & $\mathrm{a}$ & Negre & Oxidant & 3 \\
\hline 8 & I & 1 & 0 & & & 0 & & 17 & 18 & & A & 2 & II & $\mathrm{a}$ & Beige & Oxidant & 2 \\
\hline 9 & SUP & 1 & 2 & & & 0 & & 26 & & & $\mathrm{C}$ & 14 & III & $\mathrm{b}$ & Taronja & Oxidant & 2 \\
\hline 10 & II & 1 & 0 & & & 0 & & 22 & 22 & & A & 2 & I & $\mathrm{a}$ & Negre & Reductora & 2 \\
\hline 11 & SUP & 1 & 0 & & & 0 & & 36 & 36 & & A & 4 & $\mathrm{I}$ & $\mathrm{a}$ & Negre & Reductora & 2 \\
\hline 12 & SUP & 1 & 1 & & 3 & 0 & & 18 & 19 & & $\mathrm{~B}$ & 6 & II & $\mathrm{a}$ & Taronja & Oxidant & 2 \\
\hline 13 & I & 1 & 2 & & & 0 & & 12 & & & B & 8 & II & & Negre & Reductora & 1 \\
\hline 14 & II & 1 & 0 & & & 0 & & 16 & 16 & & B & 6 & I & $\mathrm{a}$ & Negre & Reductora & 2 \\
\hline 15 & II & 1 & 2 & & & 101 & & & & & $\mathrm{~F}$ & & & & Negre & Reductora & 2 \\
\hline 16 & I & 1 & 0 & & & 0 & & 32 & 32 & & A & 4 & I & $\mathrm{a}$ & Negre & Reductora & 2 \\
\hline 17 & I & 1 & 0 & & & 0 & & 22 & 22 & & $\mathrm{~A}$ & 1 & I & & Marró & Reductora & 3 \\
\hline 18 & I & 1 & 0 & & & 0 & & 12 & 13 & & $\mathrm{~B}$ & 6 & II & $\mathrm{a}$ & Negre & Reductora & 1 \\
\hline 19 & I & 1 & 0 & & & 0 & & 22 & 22 & & $\mathrm{~A}$ & 2 & I & a & Taronja & Reductora & 3 \\
\hline 20 & S.A. 2 & 1 & 0 & & & 0 & & 24 & 24 & & $\mathrm{~A}$ & 2 & I & $\mathrm{a}$ & Beige & Reductora & 3 \\
\hline 21 & S.A. 2 & 0 & & & & 431 & 432 & & & & $\mathrm{~F}$ & & & & Negre & Reductora & 2 \\
\hline 22 & I & 42 & 0 & & & 0 & & 24 & 24 & & $\mathrm{~A}$ & 2 & $\mathrm{I}$ & $\mathrm{b}$ & Negre & Reductora & 2 \\
\hline 23 & I & 71 & 0 & & & 0 & & & & & $\mathrm{~A}$ & 2 & I & $\mathrm{f}$ & Beige & Reductora & 2 \\
\hline
\end{tabular}

Fig. 12. Vasos diferenciats amb les característiques morfològiques definides, mètriques $(\mathrm{Db}$ : diàmetre de boca, Dm: diàmetre màxim $\mathrm{i}$ H: altura), tipològiques (García Borja et al. 2011), color de la superfície, cocció i gruix de paret (Gruix 1: 0-0,6cm, Gruix 2: 0,6-0,9 i Gruix 3: $0,9-2 \mathrm{~cm})$.

que recorda el boquique, encara que no és exactament aquesta tècnica. El paral·lel més proper podem trobar-lo al jaciment de Puntal de los Carniceros (Villena, Alacant) (Bernabeu 1984: 23), que també podria presentar un context del final del Calcolític campaniforme d'estil local. Les decoracions amb punxó rom en posició vertical estan documentades en altres jaciments calcolítics (Martí i Gil Sancho 1978; Pascual Benito 1988-89; Pascual i Ribera 2004). La tècnica de la incisió també es documenta en contextos eneolítics/calcolítics, trobantse fragments ceràmics d'aquesta cronologia tant en jaciments en cova (Pascual Benito 1988-89; Soler 2002) com a l'aire lliure (Pascual i Ribera 2004; García Borja 2004).

Cal destacar que totes dues tècniques estan també presents en la Muntanya Assolada (Alzira, València) (Martí 1983), poblat que ofereix materials del Bronze antic, si bé amb absència de tècniques similars al boquique.
El més destacat de l'estudi dels vasos és l'absència de contenidors de grandària mitjana i elevada, doncs a excepció del vas 9 , amb un diàmetre de boca aproximat de $26 \mathrm{~cm}$, la resta de recipients es correspon amb una vaixella senzilla i fàcilment transportable, poc típica dels assentaments en cova en què es documenta una intensa ocupació. La presència de vasos de classe $\mathrm{C}$ en contextos eneolítics, encara que minoritària, no és estranya, sobretot a mesura que avança la seqüència (García Borja 2004: 76), amb importants percentatges en moments campaniformes (Bernabeu 1984; Bernabeu i Guitart 1993).

L'existència d'un bon nombre de vasos de perfil senzill de la Classe A resulta significativa, doncs apareixen ben representats en contextos calcolítics regionals. L'absència de formes carenades i la tipologia del conjunt dels vasos, com també la presència de llavis diferenciats, permet plantejar que la majoria de la 
col·lecció ceràmica pertany al Calcolític, amb paral·lels en totes les peces al Calcolític campaniforme (25002100/2050 cal BC). Si considerem els resultats de les datacions realitzades, caldria situar el conjunt entre el Calcolític campaniforme i el Bronze antic, moments per als quals la tipologia dels vasos s'ajusta de forma coherent.

És important assenyalar que la tipologia ceràmica que es documenta en coves no és del tot coincident amb la que es troba als poblats (Soler 2002). En aquest sentit, l'absència de les típiques decoracions campaniformes en Cueva de la Diabla queda lligada amb l'absència de restes humanes i d'aixovars.

\section{INDÚSTRIA LÍTICA}

El nombre de restes d'indústria lítica recuperades ascendeix a 26 elements, pel que no és possible realitzar valoracions quantitatives. A aquestes restes cal sumar una punta de fletxa documentada en el moment de la catalogació del jaciment als anys 90 del segle XX.

Els suports són bàsicament ascles senceres o fragmentades (15 restes), i només existeix un suport laminar sobre el que s'ha fabricat una peça retocada. També s'han recuperat cinc resquills, un producte de condicionament del nucli i una peça que hem classificat amb certs dubtes com a fragment de nucli indeterminat.

La major part de les peces recuperades estan realitzades sobre sílex. Existeixen dues peces sobre calcària i una sobre quarsita. El sílex es presenta generalment patinat, tot i que existeixen algunes peces de coloracions grises.

Entre els talons conservats predominen els llisos amb aparició d'un cortical i un parell de suprimits. En les peces en què es conserva tota la part proximal s'observa un ús de la percussió directa mitjançant percussor dur.

Algunes peces presenten cúpules tèrmiques en la superfície, però en la majoria no es pot determinar si estan termoalterades, degut a la incidència de la pàtina superficial. En dues de les peces retocades (un fragment de foliaci i una punta de fletxa de peduncle $\mathrm{i}$ aletes) s'aprecien indicis d'haver estat tractades tèrmicament per a millorar la seua talla.

\section{LES PECES RETOCADES}

Les peces retocades ascendeixen únicament a quatre. La primera és una punta de fletxa amb peduncle $i$ aletes (fig. 13,1), apareguda en la capa 14 del sondeig 3 (Nivell I).

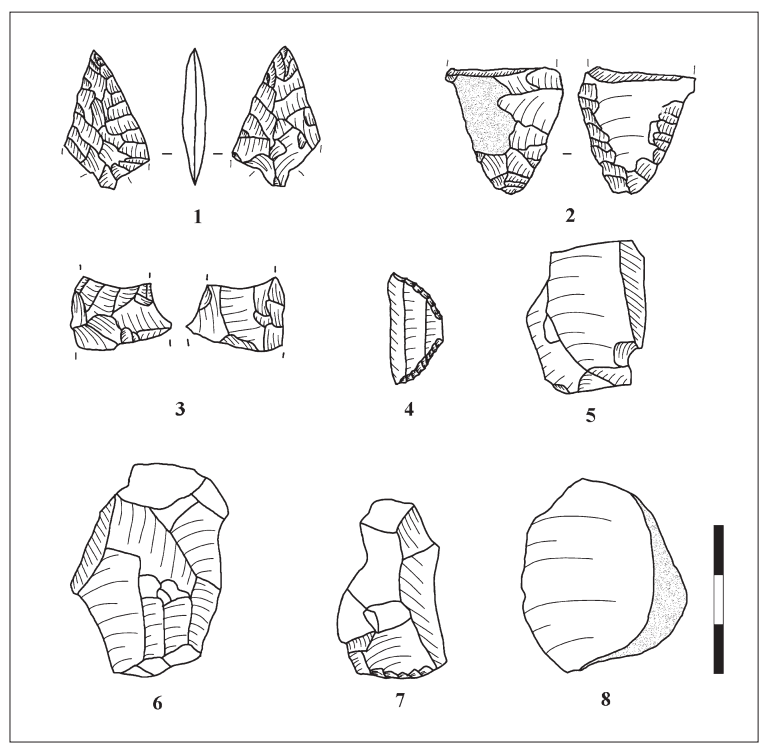

Fig. 13. Indústria lítica tallada.

Es tracta d'una punta amb unes dimensions de $27,8 \mathrm{~mm}$ de longitud, 17,1 mm d'amplària i un gruix de 4,2 mm. Presenta fracturades les dues aletes. El retoc és pla, cobrent i bifacial. Es pot observar que ha estat sotmesa a un tractament tèrmic.

La segona és un fragment de peça foliàcia (fig. 13,2), procedent de la capa 17 del sondeig 3 (Nivell II). Es tracta d'una fractura que molt possiblement s'ha produitt durant el procés de fabricació. En la cara dorsal presenta retocs plans en tot el costat dret i la part proximal de l'esquerre, quedant cortical la resta. La cara ventral té un retoc simple profund en els dos costats.

La tercera és un fragment de punta de fletxa (fig. 13,3), apareguda en la capa 19 del sondeig 3 (Nivell II). Es tracta d'un petit fragment medial d'una peça foliàcia $\mathrm{amb}$ retocs bifacials i restes de tractament tèrmic.

Finalment, la quarta és un trapezi simètric (fig. 13,4) recuperat en la capa 25 del sondeig 3 (Nivell III). Està fabricat sobre un fragment de làmina, i posseeix unes dimensions de 21,3 mm de longitud, 9,8 mm d'amplària i un gruix de 2,4 mm. Les dues vores retocades presenten retocs abruptes, però en la part distal són inversos i en la proximal directes. Tot i ser classificat com a trapezi, cal apuntar que la vora retocada és un poc arquejada degut a una lleugera convexitat de les dues fractures retocades, especialment la distal, el que li dóna un cert aspecte de mitja-lluna i permet incloure'l en el tipus G10 de la tipologia de Juan-Cabanilles (2008). 


\section{VALORACIÓ DEL CONJUNT}

Únicament dues peces ens poden marcar dades cronològiques més o menys concretes, la punta de peduncle $i$ aletes i el trapezi, encara que amb aquest baix nombre de peces és difícil arribar a unes conclusions amb un alt grau de coherència.

La punta, tot i presentar les aletes fracturades, ens remet a contextos eneolítics-calcolítics o del Calcolític campaniforme (Juan-Cabanilles 2008), tot i que la seua aparició és lleugerament anterior. El resultat de les datacions radiocarbóniques possibiliten plantejar que aquestes puntes foren de l'Edat del Bronze. L'aparició en contextos del Bronze antic (Martí 1983) d'aquestos elements reforça aquesta proposta, no així en moments avançats, doncs l'aparició a Cueva de la Diabla no mereix la mateixa interpretació que als jaciments del Bronze Mitjà-Tardà (Jover 2008). Tot i això, el conjunt de la industria lítica recuperat remet a moments del Calcolític campaniforme.

El trapezi tampoc ens permet afirmar amb seguretat la seua pertinença a un moment concret. L'aparició d'aquests elements es produeix en moments del Mesolític geomètric, desenvolupant-se també durant tot el Neolític. En aquest cas però, la tipologia de l'exemplar recuperat sembla portar-nos també a moments recents. Hem de tindre en compte que aquesta peça es va recuperar en una capa amb escàs material arqueològic (Nivell III) i que per sota de la qual tampoc es va trobar cap element ceràmic. Malauradament es trobava dins d'un cau, pel que la fiabilitat de la seua posició cronostratigràtica és molt reduïda.

\section{LA FAUNA}

Encara que hem analitzat totes les restes òssies recuperades a la cova, en aquest punt anem a reflexionar sobre les recuperades al Nivell II, úniques que presenten certa entitat estratigràtica. Cal assenyalar que en la revisió de tot el material recuperat a la cova no hem constatat l'existència d'ossos humans.

El total de restes estudiades del Nivell II ascendeix a 549 , repartides en les diferents capes (fig. 14). Els taxons identificats i les restes no determinades s'arrepleguen a la figura 15. La primera dada a destacar és l'elevada presència de restes de conill, si bé el seu origen, com detallarem en l'estudi tafonòmic, no sembla exclusivament antròpic.

Entre les restes d'animals aportats amb seguretat pels grups humans cal destacar l'elevada presència d'espècies salvatges, especialment de cérvol (Cervus

\begin{tabular}{|l|c|}
\hline \multicolumn{1}{|c|}{ Capa } & Total \\
\hline 14 & 84 \\
15 & 74 \\
16 & 47 \\
17 & 87 \\
18 & 37 \\
19 & 62 \\
20 & 22 \\
22 & 1 \\
$14-15$ & 22 \\
$16-17$ & 24 \\
$21-22$ & 68 \\
Interior Llar & 2 \\
Netetja Llar & 19 \\
\hline Total & 549 \\
\hline
\end{tabular}

Fig. 14. NR absolut estudiades a cada capa del Nivell II.

elaphus) (NR=49), així com de cabra salvatge (Capra pyrenaica) $(\mathrm{NR}=14)$, front a les escasses restes identificades d'animals domèstics, ovella i/o cabra domèstica (NR total per als dos gèneres=7). Cal tenir present, però, que hi ha 24 restes classificades com a Caprinae que no han pogut ser identificades amb seguretat com a ovella, cabra salvatge o cabra domèstica. L'aportació humana d'aquestos taxons queda demostrada per l'aparició de marques antròpiques relacionades amb el processat carnisser.

S'han identificat un total de nou marques d'incisions sobre ossos de cérvol, cabra salvatge i conill. En el cas dels ossos de cérvol, apareixen dos talls molt probablement per l'escorxat de l'animal sobre una falange primera i un metatars, $i$ altres tres relacionats segurament amb el descarnament sobre un radi, una ulna i un coxal. En el cas de la cabra salvatge les incisions apareixen sobre dos metacarps. En els dos casos són transversals i relacionades amb l'escorxat. En el ossos de conills els ossos afectats són dos coxals.

També s'han identificat una sèrie de fractures antròpiques que afecten a ossos de cérvol, cabra salvatge i conill. En el cas del cérvol hi ha tres ossos fracturats, solament un en el cas de la cabra, un altre d'ovella o cabra domèstica molt jove i 18 de conill. Especialment destacable és el cas de l'húmer d'ovella o cabra jove. Presenta una fractura on les vores afectades mostren un peeling derivat d'un mos i probablement d'una flexió sincrònica (Sanchis et $a l$.e.p.). Aquestes marques són semblants a les que poden deixar els atacs dels carnívors, si bé no presenten arrossegaments o puncions fortes associades, que sí 
Pablo García Borja, Yolanda Carrión Marco, José Enrique López Peris, Juan Vicente Morales Pérez, Salvador Pardo Gordó, Felip Pérez i Ferrer, Guillem Pérez Jordà, Dídac Roman Monroig, Pablo Sañudo Die, Carlos Verdasco Cebrián

\begin{tabular}{|c|c|c|c|c|c|c|c|c|c|c|c|c|c|}
\hline Taxó & 14 & $14-15$ & 15 & 16 & $16-17$ & 17 & 18 & 19 & 20 & $21-22$ & 22 & Llar & Total \\
\hline Capra cf. hircus & & & 1 & & & & & & & & & & 1 \\
\hline Ovis aries & & & & & & 1 & & & & & & & 1 \\
\hline Ovis/Capra & 4 & 1 & & & & & & & & & & & 5 \\
\hline Capra pyrenaica & & & 2 & & & 3 & & 2 & 3 & 4 & & & 14 \\
\hline Caprinae & 1 & 1 & 5 & 7 & 1 & 5 & 1 & 1 & & & & 2 & 24 \\
\hline Cervus elaphus & 5 & 4 & 4 & 4 & 2 & 12 & & 12 & 1 & 5 & & & 49 \\
\hline Equus sp. & & & & & 1 & & & & & & & & 1 \\
\hline Sus sp. & & 1 & & 1 & & & & & & & & & 2 \\
\hline Vulpes vulpes & & & 1 & & & & & & & & & & 1 \\
\hline Oryctolagus cun. & 41 & 11 & 21 & 20 & 13 & 24 & 17 & 22 & 10 & 36 & & 11 & 226 \\
\hline Avifauna & & & & & & 1 & & & & & & & 1 \\
\hline Mesof & 21 & 3 & & 7 & 6 & 21 & 19 & 2 & 8 & 5 & 1 & 9 & 101 \\
\hline Indet & 12 & 1 & 40 & 8 & 1 & 20 & & 23 & & 18 & & & 123 \\
\hline Total & 84 & 22 & 74 & 47 & 24 & 87 & 37 & 62 & 22 & 68 & 1 & 21 & 549 \\
\hline
\end{tabular}

Fig. 15. NR dels diferents taxons identificats i restes no identificades a les diferents capes estudiades.

apareixen en els ossos afectats per aquests animals. El seu aspecte i la semblança amb materials experimentals i etnogràfics (Landt 2004 i 2007) suggereix la possibilitat que les marques siguen d'origen antròpic, més si considerem que la curta edat de l'animal facilitaria el consum d'aquesta articulació. A banda de les restes taxonòmicament identificades, s'han detectat dues mosses de percussió antròpica en dos fragments d'ossos llargs de mesofauna.

Hem documentat la presència de marques de carnívors en 20 restes òssies. Una d'elles, sobre ovella o cabra, mostra senyals en la zona proximal provocades pel rossegat d'un carnívor; en el cas de la cabra salvatge, en l'articulació distal d'un metacarp. El cérvol presenta sis restes afectades, cinc rossegades i una fracturada per un potent mos que ha deixat una clara mossa associada a puncions. En el cas del conill, trobem cinc ossos amb marques clares de carnívor. Tres d'aquests (ulna, coxal i metatars) presenten marques provocades per mamífers carnívors sense que puguem precisar si es tracta de carnívors salvatges o de gossos domèstics. Una altra ulna apareix digerida sense poder determinar el depredador, i per últim un coxal mostra una mossa que és molt semblant a les que apareixen en els conjunts d'aus rapinyaires provocades pel bec del depredador (Sanchis 2000). Tanmateix, al tractarse d'una única resta, no es pot afirmar que l'agent acumulador siga diferent als mamífers carnívors.

Per tant, cal admetre que la presència de gran part de la macrofauna salvatge del Nivell II és consequiència de l'aportació humana. Les restes arqueològiques que hem exposat i la presència de restes d'ovella, confirmen que

\begin{tabular}{|l|c|}
\hline \multicolumn{1}{|c|}{ Os } & NR \\
\hline Crani & 2 \\
Mandíbula & 3 \\
Dent & 4 \\
\hline Vèr .cervical & 2 \\
Vèr. toràcica & 1 \\
Costella & 1 \\
\hline Escàpula & 1 \\
Húmer & 1 \\
Radi & 1 \\
Ulna & 2 \\
Carp & 2 \\
Metacarp & 8 \\
\hline Coxal & 3 \\
Fèmur & 1 \\
Tíbia & 8 \\
Astràgal & 1 \\
Metatars & 6 \\
\hline Falange I & 2 \\
\hline Total & 49 \\
\hline
\end{tabular}

Fig. 16. Unitats anatòmiques identificades de Cervus elaphus.

estem davant d'un grup humà d'economia productora. Però el tret més important del conjunt faunístic del Nivell II és, sense dubte, l'elevada presència de restes de cérvol i cabra salvatge, molt més elevada que la d'animals domèstics.

Existeix un bon nombre de conjunts del III mil·lenni a.C. amb elevada presència d'animals salvatges, principalment cérvol si obviem el conill. Els exemples més significatius són Ereta del Pedregal (Pérez Ripoll 1990 i 


\begin{tabular}{|l|cccc|}
\hline \multicolumn{1}{|c|}{ Taxó } & Adult & Subadult & Jove & Nounat \\
\hline Ovis aries & 1 & & & \\
Ovis/Capra & & & 5 & \\
Capra pyrenaica & 3 & & 1 & \\
Caprinae & 3 & & 4 & 10 \\
Cervus elaphus & 10 & 4 & 4 & 1 \\
Equus sp. & 1 & & & \\
Sus sp. & 1 & & & 1 \\
Vulpes vulpes & 1 & & & \\
Oryctolagus cun. & 52 & & 1 & 20 \\
\hline Total & 71 & 4 & 15 & 32 \\
\hline
\end{tabular}

Fig. 17. Restes dels diferents taxons organitzades per cohorts d'edat.

1999) o Fuente Flores (Juan-Cabanilles i Martínez 1988). Tot indica que la cacera és una activitat econòmica important, com a mínim en determinades zones en les que el medi ho permet, doncs els jaciments d'aquesta cronologia que es troben en un medi més antropitzat mostren una importància major del ramat domèstic, com ocorre a Niuet (Pérez Ripoll 1999), Jovades (Martínez Valle 1993), Colata (López Gila 2004) o Arenal de la Costa (Martínez Valle 1993). En aquest context, jaciments com el que ens ocupa podrien ser llocs d'explotació de recursos salvatges: cérvol i cabra salvatge. L'abundància de restes salvatges aportades per l'activitat humana ens plantejava diferents possibilitats. En aquest sentit, una de les qüestions a abordar era si s'estaven processant les restes en la cova abans de traslladar-les a altre lloc d'hàbitat principal. Les restes de cérvol són les úniques que per quantitat de restes i per resultat, poden aportar alguna mena d'informació mitjançant l'estudi de la freqüència de les parts anatòmiques (fig. 16). Els resultats d'aquest estudi mostren una preeminència de les parts distals de les extremitats (metàpodes), si bé l'absència de falanges, tret de dues primeres, no es correspon amb la lògica d'una separació dels extrems articulars a la cova i el transport de la resta de les potes al suposat poblat. Malgrat que el cérvol és el taxó millor representat, el baix nombre de restes no permet realitzar afirmacions en aquest sentit.

Tot i les poques restes identificades, sí que hem pogut extraure algunes consideracions interessants de l'estudi de les edats de mort (fig. 17). Documentem un patró d'edats en el cas del cérvol que pot reflectir una cacera d'ampli espectre, no selectiva pel que fa a les edats. Així mateix, la presència d'una resta d'un cérvol nounat confirma l'ocupació de la cova com a mínim a primeries de l'estiu (Blanco 1998: 130), moment en què el clima de l'entorn de la cova és més suau i transitable. Un altre aspecte que podem destacar és la important presència de restes de catxaps que deuen estar relacionades amb l'elevat nombre de caus existents en el jaciment, i per tant originats per morts naturals.

\section{LES RESTES DE CARBÓ VEGETAL}

La seqüència antracològica de Cueva de la Diabla cobreix, almenys, dos moments sedimentaris ben diferenciats: un corresponent al paquet d'ocupació prehistòrica (Nivell II), i un altre (Nivell III), d'aspecte natural (sorres taronges), en què probablement la cova es troba desocupada o les ocupacions són tan esporàdiques que quasi no deixen restes materials en els nivells arqueològics. No obstant això, el registre antracològic d'aquest moment és relativament ric, encara que l'absència d'altres materials es quasi total en aquest paquet.

La hipòtesi plantejada per explicar la presència sistemàtica de carbó en el Nivell III (capes 24 a 31) és que aquest siga el resultat d'una percolació de les capes superiors en contacte, produïda, per exemple, per l'existència de caus, encara que s' han intentat evitar sistemàticament durant el mostreig del carbó. En el Nivell II (capes 14 a 22), la presència de carbó junt a altres materials arqueològics indica que aquest és resultat de l'activitat humana en la cova. No obstant, tampoc podem descartar que s'intercalen en aquestes capes restes d'episodis d'incendis exteriors, sedimentats en la cova per causes naturals.

Malgrat l'aparent brevetat de l'ocupació prehistòrica, la sequiència antracològica s'integra en el marc de la discussió sobre la neolitització de la regió i l'efecte d'aquesta economia en el paisatge vegetal en zones perifèriques per a l'agricultura, on la principal activitat que hem pogut documentar és la cacera, i que a priori degué de provocar un escàs impacte en l'evolució natural de la vegetació dels voltants de la cova.

\section{L'ENTORN VEGETAL DE CUEVA LA DIABLA}

Actualment, Cueva de la Diabla es localitza al pis bioclimàtic mesomediterrani, en un ombroclima sec, a uns 1000 m d'altitud (Costa 1982). La vegetació de la zona té un caràcter de transició entre les formacions sublitorals llevantines i el pla continental castellà-manxego. A l'entorn més immediat de la cova és abundant el pi pinastre (Pinus pinaster) i la carrasca (Quercus rotundifolia), i un dens matoll format per romer (Rosmarinus 
Pablo García Borja, Yolanda Carrión Marco, José Enrique lópez Peris, Juan Vicente Morales Pérez, Salvador Pardo Gordó, Felip Pérez i Ferrer, Guillem Pérez Jordà, Dídac Roman Monroig, Pablo Sañudo Die, Carlos Verdasco Cebrián

\begin{tabular}{|c|c|c|c|c|c|c|c|c|c|c|c|c|c|c|c|c|}
\hline \multirow{2}{*}{$\begin{array}{l}\text { Nivell arqueològic } \\
\text { Taxons/Capa }\end{array}$} & \multicolumn{7}{|c|}{ II } & \multicolumn{6}{|c|}{ III } & \multicolumn{2}{|c|}{ Total } & \multirow{2}{*}{$\begin{array}{r}\text { Llar } \\
N^{0} \\
\end{array}$} \\
\hline & 14 & 15 & $16 / 17$ & 18 & 19 & 20 & $21 / 22$ & $24 / 25$ & 26 & 27 & 28 & 29 & 31 & $\mathbf{N}^{\mathbf{o}}$ & $\%$ & \\
\hline Acer sp. & & 1 & & & & & 1 & 1 & & & & & & 3 & 0,28 & \\
\hline Arbutus unedo & 7 & 4 & & & 2 & & 7 & 11 & 12 & 6 & 13 & 1 & 7 & 70 & 6,56 & 1 \\
\hline Compositae & 1 & & & & & & & 2 & & & & & & 3 & 0,28 & \\
\hline Erica sp. & & & & & & & & & 1 & & & & & 1 & 0,09 & \\
\hline Ficus carica & & & 1 & & & & & & & & & & & 1 & 0,09 & \\
\hline Fraxinus sp. & 6 & 3 & 4 & & 2 & & 3 & 1 & 1 & & 1 & & & 21 & 1,97 & \\
\hline Juniperus sp. & & 1 & 2 & & & & & 3 & & 2 & 1 & & & 9 & 0,84 & \\
\hline Olea europaea & & & & & & & & 1 & & & & & & 1 & 0,09 & \\
\hline Pinus halepensis & 6 & 7 & 2 & & & & & 5 & 4 & 11 & 4 & 1 & 1 & 41 & 3,84 & 2 \\
\hline Pinus nigra-sylvestris & & & & & 1 & & 1 & & & 1 & & & & 3 & 0,28 & \\
\hline Pinus pinaster & 18 & 25 & 56 & 29 & 16 & 20 & 34 & 38 & 33 & 17 & 63 & 13 & 3 & 365 & 34,21 & 8 \\
\hline Pinus cf. P. pinaster & 1 & & & & & 1 & 1 & 3 & 3 & & 5 & 1 & 1 & 16 & 1,50 & \\
\hline Pinus pinaster-P. pinea & & & 1 & & & 1 & & & & & 1 & & & 3 & 0,28 & \\
\hline Pinus sp. & 26 & 14 & 50 & 10 & 10 & 18 & 23 & 28 & 18 & 20 & 23 & 12 & 13 & 265 & 24,84 & 12 \\
\hline Pistacia lentiscus & & & & & & & & 5 & 1 & 2 & 2 & & 1 & 11 & 1,03 & \\
\hline Quercus caducifoli & 6 & 4 & 9 & 3 & 5 & 4 & 16 & 11 & 11 & 7 & 11 & & & 87 & 8,15 & \\
\hline Quercus perennifoli & 5 & 4 & 1 & 1 & 2 & 1 & 2 & 3 & 5 & 7 & 11 & & & 42 & 3,94 & 4 \\
\hline Quercus sp. & 1 & & 2 & & 1 & & & 3 & & 1 & 1 & & & 9 & 0,84 & \\
\hline Rhamnus-Phillyrea & & & & & & & & 1 & & & 1 & & & 2 & 0,19 & \\
\hline Rosmarinus officinalis & 6 & 6 & 3 & 3 & & 3 & 3 & 8 & 9 & 7 & 10 & & & 58 & 5,44 & 1 \\
\hline Coniferae & 4 & 1 & 3 & 3 & 2 & & 1 & 2 & 1 & & 4 & 3 & 2 & 26 & 2,44 & 2 \\
\hline Indeterminable & & & 1 & 1 & 4 & 2 & 8 & 4 & 1 & 4 & 1 & 2 & 2 & 30 & 2,81 & \\
\hline Total & 87 & 70 & 135 & 50 & 45 & 50 & 100 & 130 & 100 & 85 & 152 & 33 & 30 & 1067 & 100 & 30 \\
\hline $\mathrm{N}^{0}$ mín. espècies & 8 & 9 & 8 & 4 & 6 & 4 & 8 & 13 & 9 & 9 & 10 & 3 & 4 & & & 5 \\
\hline
\end{tabular}

Fig. 18. Freqüències dels taxons vegetals identificats al carbó dels Nivells II i III de Cueva de la Diabla.

officinalis), bruc d'hivern (Erica multiflora), argelagues (Ulex), càdec (Juniperus oxycedrus), estepa blanca (Cistus albidus) i espart (Stipa tenacissima). L'abundant presència actual del pi pinastre (Pinus pinaster) en la zona està associada a sòls ben desenvolupats d'origen calcari que han patit un procés previ de descarbonatació (Peris Gisbert i Sanchís Duato 1996); els mateixos enclavaments acullen la presència del pi pinyoner $(P$. pinea $)$, encara que aquest és resultat de repoblacions recents per a l'aprofitament del seus fruits.

L'anàlisi antracològica corrobora la importància de les pinedes des de cronologia calcolítica, i no tan sols com un efecte posterior d'activitats humanes de desforestació i repoblació. La vegetació de l'entorn de Cueva de la Diabla durant el Calcolític estava clarament dominada per formacions de pineda (figs. 18 i 19), entre les quals s'han identificat al menys tres espècies diferents de pi d'ecologia diversa (fig. 20). El més abundant és el pi pinastre, encara que també està present el pi blanc (Pinus halepensis) i, més esporàdicament, els pins de muntanya
(P. nigra-sylvestris). Les diferents espècies de pins són grans indicadors de temperatura i de condicions edàfiques. La qualitat del carbó de la cova ha permès identificar un alt percentatge de pins fins a l'espècie, però és cert que un altre gran nombre s'ha quedat només en el rang del gènere (Pinus sp.).

La presència del pi pinastre en l'entorn de la cova durant el Calcolític final s'emmarca en una interessant discussió sobre el caràcter autòcton d'aquesta espècie a la península Ibérica i sobre l'origen de les poblacions actuals, la distribució natural de les quals ha quedat difuminada per la intensa repoblació des d'època romana fins a l'actualitat. Les dues qüestions es van tancant davant de les nombroses dades pol-líniques i antracològiques que documenten la presència del pi pinastre des de moments antics en gran part del territori peninsular (Figueiral 1995; Ramil-Rego 1992; Reille i Lowe 1993; Mateus i Queiroz 1993; Dupré 1988; Carrión et al. 2000). Aquests estudis indiquen que el pi pinastre persistí durant l'ultima glaciació i s'expandí en moments 


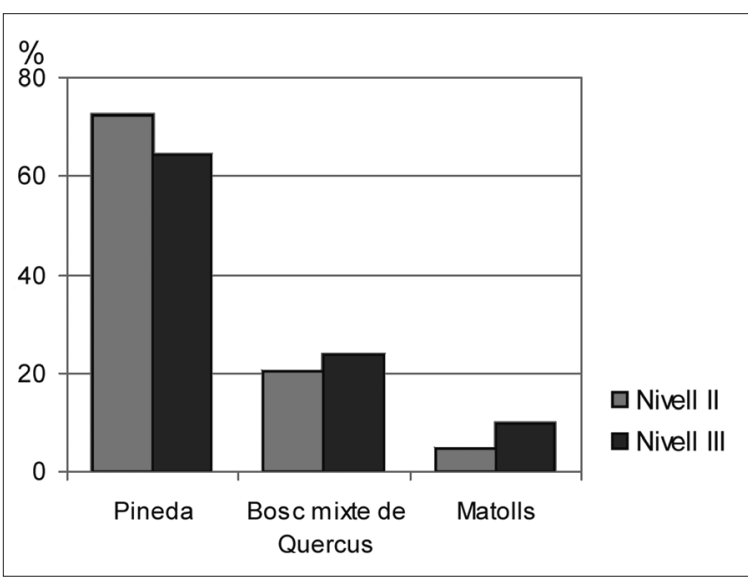

Fig. 19. Principals formacions vegetals identificades al carbó de Cueva de la Diabla.
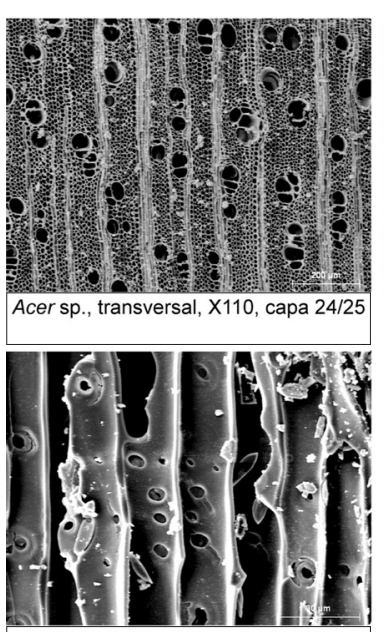

Pinus halepensis, radial $\mathrm{X} 900$,

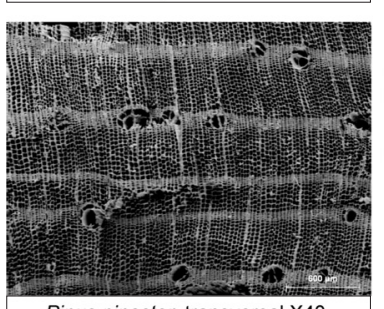

Pinus pinaster, transversal $\mathrm{X} 40$ capa 17

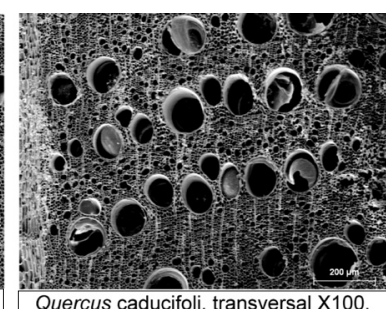

capa 17
cali, trans

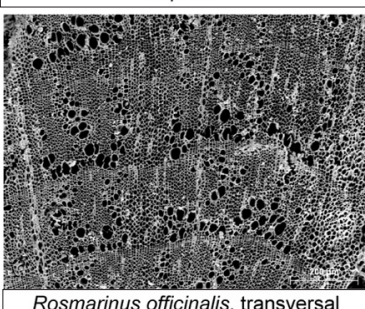

Rosmarinus officinalis, transversal
X110, capa 28

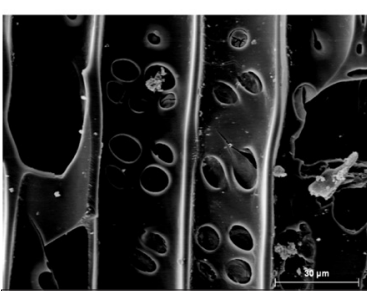

Pinus pinaster, radial $\mathrm{X} 900$, capa 17

Fig. 20. Fotos de microscopi electrònic d'alguns dels taxons identificats.

postglacials des de diversos refugis per tot el territori peninsular. La presència de pinastre a La Diabla en cronologies prehistòriques recolza el seu caràcter autòcton en la façana oriental peninsular i la seua abundància en

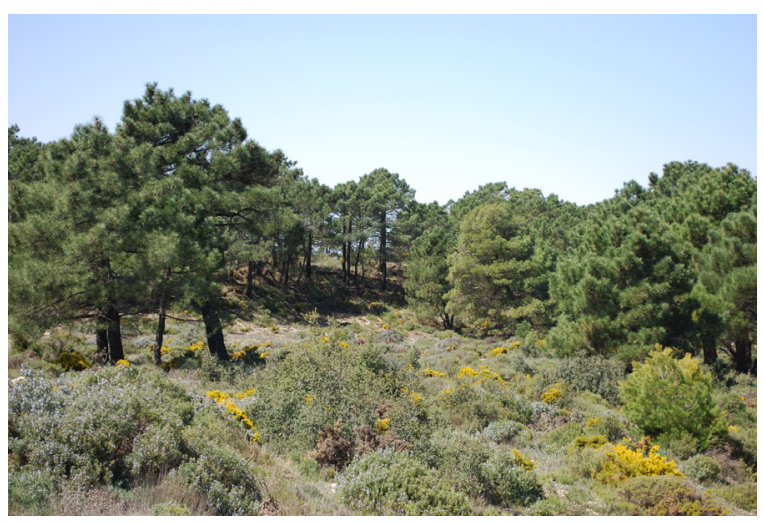

Fig. 21 Fotografia de pinars de pi pinastre en l'entorn de Cueva de la Diabla.

l'entorn del jaciment, probablement afavorida per una supervivència i adaptació als episodis de foc ocorreguts en la zona (Tapias et al. 2001). Pel que fa al pi pinyoner, aquesta espècie no s'ha identificat amb seguretat a la Cueva de la Diabla, de manera que és possible que la seua presència actual a la zona es dega únicament a repoblacions més recents. Finalment, els pins de muntanya estan poc representats.

A més de la pineda, en el carbó es detecta en menor mesura la presència d'altres formacions, entre elles, de Quercus caducifoli i perennifoli, acompanyats d'arbocer (Arbutus unedo) i freixe (Fraxinus sp.). La imatge general seria coherent amb l'existència de pinedes i de bosquets mixtos de Quercus amb presència de caducifolis, probablement relegats a enclavaments edàfics benignes.

També es desenvoluparien espècies de requeriments més càlids, com el llentiscle (Pistacia lentiscus) o l'ullastre (Olea europaea). El sotabosc està escassament atestat amb la presència del romer (Rosmarinus officinalis) i el llentiscle principalment, encara que també estan presents més esporàdicament altres matolls (Erica sp., Rhamnus-Phillyrea, Composita, Olea europea). La identificació de rizomes d'espart (Stipa tenacíssima) indica la presència d'aquesta espècie ja en cronologies prehistòriques.

La vegetació representada en el carbó de Cueva de la Diabla és principalment boscosa, com encara en queden restes prop de la cova (fig. 21), de manera que podem suposar que la importància relativa del matoll fóra reduïda; no obstant això, també pot ser degut a un problema de registre, com que aquest estrat de vegetació fos menys explotat pels humans o que les seues restes 
Pablo García Borja, Yolanda Carrión Marco, José Enrique López Peris, Juan Vicente Morales Pérez, Salvador Pardo Gordó, Felip Pérez i Ferrer, Guillem Pérez Jordà, Dídac Roman Monroig, Pablo Sañudo Die, Carlos Verdasco Cebrián

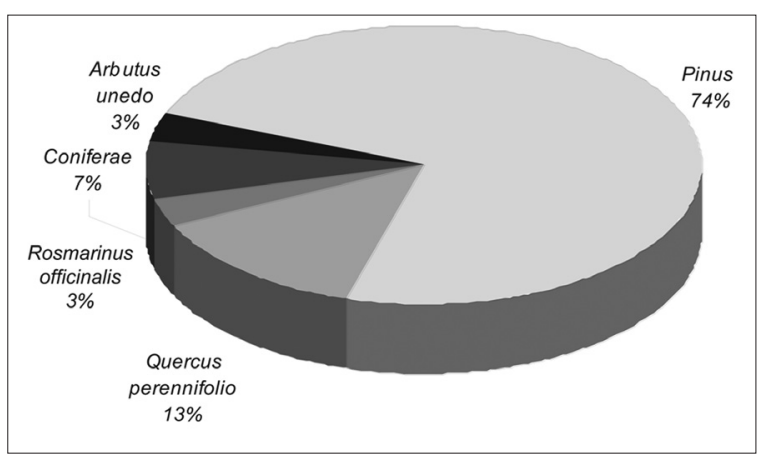

Fig. 22. Composició de les restes vegetals de la Llar.

carbonitzades no arribaren a sedimentar-se en la cova. Actualment, aquestes formacions tenen una gran entitat en la zona com a resultat d'una intensa desforestació (Costa i Peris 1984).

\section{LA LLENYA PER AL FOC}

El conjunt de taxons identificats al carbó de Cueva de la Diabla ens remet a les formacions vegetals existents en l'entorn de la cavitat durant el Calcolític, que van ser explotades pels humans que allà es van assentar. No existeixen diferències significatives entre els espectres de vegetació dels Nivells II i III (fig. 19), de manera que es corrobora que: 1) tot el carbó pertany a un mateix paquet d'ocupació no molt dilatada en el temps; 2) es recull l'ampli espectre d'espècies disponibles; i/o 3) durant el temps que dura l'ocupació, hi ha un escàs impacte de l'activitat humana en la vegetació de l'entorn de la cova.

L'única estructura documentada com un possible foguer in situ ha proporcionat escasses restes de carbó en comparació amb la quantitat de restes disperses per la corresponent capa arqueològica. Açò és un fet freqüent: malgrat l'aparença carbonosa del foguer, la major part es composava de cendres que havien arribat a un grau de calcinació total, quedant tot just uns quants fragments de fusta en forma de carbó. En tot cas, la presència dels tàxons identificats en aquesta estructura avala l'ús de les espècies descrites per a tot el paquet d'ocupació, és a dir, una presència massiva dels pins (fig. 22).

Probablement, totes les espècies explotades es trobarien prop de la cova: atès que tot apunta que es tracta d'una ocupació esporàdica, no és factible pensar en un sobre-esforç de transport de llenya des d'enclavaments més allunyats. Així doncs, les necessitats bàsiques de llenya (per escalfar-se, processar aliments, espantar animals, etc.), quedarien cobertes amb els recursos vegetals dels voltants.

\begin{tabular}{|c|c|c|}
\hline Capa & $21-22$ & 24 \\
\hline Cuadro & C11-D11 & D11 \\
\hline Triticum aestivum-durum & 1 & 1 \\
\hline Stipa tenacissima rizoma & & 1 \\
\hline
\end{tabular}

Fig. 23. Llavors recuperades.

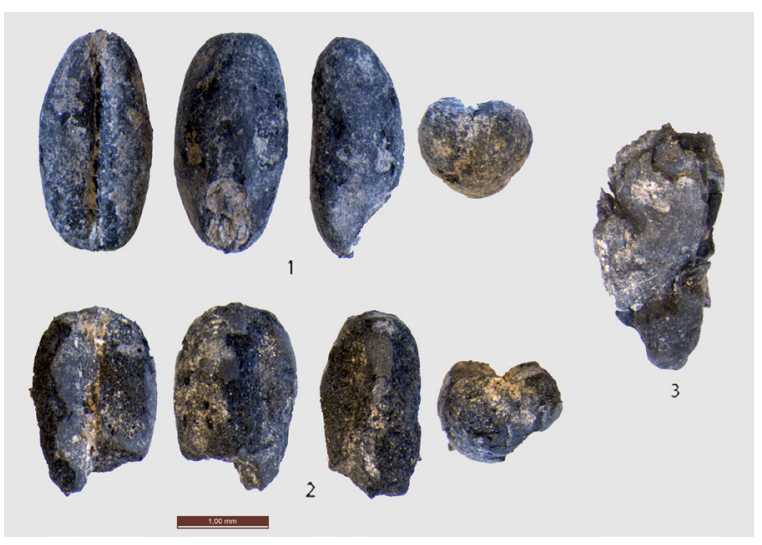

Fig. 24. Restes vegetals. 1 i 2 Triticum aestivum-durum, 3. Stipa tenacissima.

\section{LES RESTES CARPOLÒGIQUES}

El registre carpològic d'aquesta cavitat ha resultat molt escàs. Sols hem pogut recuperar materials en dues de les capes diferenciades (fig. 23) i entre els materials determinats sols podem assenyalar la presència entre els cereals dels blats nus (Triticum aestivum-durum), a més d'un rizoma d'espart (Stipa tenacissima) (fig. 24).

Els blats nus, junt a l'ordi nu (Hordeum vulgare var. nudum) són des del VI milllenni a.C., una de les bases fonamentals de la cerealicultura desenvolupada al País Valencià. El primer és el cereal panificable per excel-lència i el preferit per a l'alimentació humana fins a l'actualitat. En aquest sentit, les dades de Cueva de la Diabla serien una nova constatació d'aquest fet a finals del III mil·lenni a.C.

L'únic jaciment proper des del punt de vista geogràic i cronològic que té registre carpològic és Ereta del Pedregal (Navarrés). Aquest és molt similar al que hem pogut documentar en diferents jaciments de les valls del Serpis i de l'Albaida (Bernabeu 1993; Gómez Puche et al. 2004; Pérez Jordà i Carrión Marco 2011): predomini dels cereals, principalment blat nu i ordi nu. Una presència reduïda de lleguminoses i l'aparició d'un conreu nou al nostre territori com és el lli. El registre de plantes silvestres que pogueren haver estat recol·lectades per a l'alimentació 
humana està absent o és molt pobre en totes les àrees. I aquest fet és especialment destacable en Cueva de la Diabla, un assentament des del que suposadament no s'estaria realitzant cap activitat agrícola, ja que l'entorn no és molt favorable. Hauríem de pensar més bé en que les restes que trobem ací serien traslladades com a aliment per les persones que utilitzaren la cavitat, des dels assentaments permanents ubicats a les planes properes des dels quals es realitza l'explotació agrària del seu entorn.

Per tant, actualment no tenim elements per a pensar que hi haguera una diferència a l'hora d'escollir les espècies a conrear entre zones que presumiblement conten amb una tradició agrària molt més arrelada i aquesta zona interior, on l'agricultura podria haver arribat en un moment més tardà.

La presència de rizomes d'espart en jaciments prehistòrics és un fet habitual. La seua lectura es problemàtica, ja que podrien arribar al jaciment tant per l'ús de la planta com a combustible, com per la seua recol-lecció per a obtenir la fibra vegetal. En aquest darrer cas la documentació etnogràfica assenyala l'interès d'extreure sols la fulla i no el rizoma, ja que és el que assegura la reproducció de la planta. Per aquest motiu es podria pensar, si aquest fora el cas, en un sistema de recollida menys conservador que afectés igualment a la part radicular.

\section{EL CONJUNT DE LES DADES}

Els resultats que hem presentat no son conseqüència d'una excavació en extensió, però permeten realitzar algunes consideracions interessants al respecte de la cronologia i funcionalitat de la cova.

La seqüència arqueològica que hem establert mostra un primer moment d'ocupació al Calcolític. Encara que el material arqueològic no resulta completament definitori, les datacions radiocarbòniques ens ofereixen un context d'ocupació inicial als moments finals del Calcolític campaniforme, inicis de l'Edat del Bronze.

No descartem completament l'existència d'alguna inhumació, però en aquests moments no podem interpretar el registre com el resultat d'un ús sepulcral de la mateixa. Cal plantejar el seu ús com a lloc ocupat de forma esporàdica o estacional al final del Calcolític campaniforme i Bronze antic, en cap cas un hàbitat estable. En aquest sentit, la inexistència de sols adequats en l'entorn immediat per a l'activitat agrària i les dures condicions climatològiques que a l'hivern existeixen al seu entorn immediat, també expliquen la dificultat de que fos habitada de forma estable.
La vaixella analitzada és senzilla, amb escasses decoracions i sense contenidors de grandària important. Tampoc sembla detectar-se una activitat de talla de sílex, ja que les restes són escasses, cal destacar un geomètric i dues puntes de fletxa.

La lectura que realitzem de la presència d'una llar associada al conjunt de restes arqueològiques del $\mathrm{Ni}$ vell II, és la d'un d'aquests contextos d'ocupació esporàdica. Sembla lògic plantejar que als voltants de la cova es realitzaven activitats cinegètiques, fet que no sols es deriva de la presència de puntes de fletxa, també del resultats obtinguts a l'estudi de la fauna, que demostra que part dels ossos han sigut aportats per l'activitat humana, destacant l'elevada presència de restes d'animals salvatges, especialment cabres i cérvols. En aquest sentit, les dades antracològiques mostren un paisatge poc antropitzat, on l'activitat humana no ha incidit de forma notable, i en el que els animals salvatges serien abundants. La ubicació de la cova junt a un assagador amb categoria de "Cañada Real" que comunica el nucli de jaciments de la Canal de Navarrés amb Almansa, creguem està directament relacionada amb l'ocupació de la mateixa, com a lloc de descans de viatgers o de caçadors.

Els voltants de la cova presenten un entorn propici per a la cacera, i no tant per a la pràctica d'activitats agrícoles. Resulta complicat demostrar si la utilització d'animals salvatges com a aliment és el resultat del seu ús com a lloc de descans de ramaders o de viatgers, o si es utilitzat com a lloc satèl-lit d'un llogaret per tal de realitzar activitats de cacera, com a complement de la ramaderia i a l'agricultura. Hem comentat la dificultat que presenten les restes de fauna des de la perspectiva tafonòmica a l'hora de defensar una activitat de processat d'animals a la cova. Però cal destacar que no hem identificat cap nivell sedimentològic relacionat amb l'ús com a corral de la cova en cronologies prehistòriques.

Entre els materials arqueològics, no s'han documentat restes de coure o bronze, formes carenades o dents de falç, però sí un fragment decorat amb impressions utilitzant una tècnica que recorda al boquique, raó per la qual no descartem que podria haver estat ocupada en moments avançats de l'Edat del Bronze, època en la que es documenta una major concentració de jaciments al terme d'Ayora (Poveda 2001). Però tot el material prehistòric, inclòs aquest fragment ceràmic, pot ubicar-se al final del Calcolític i/o Bronze antic. El conjunt de les 


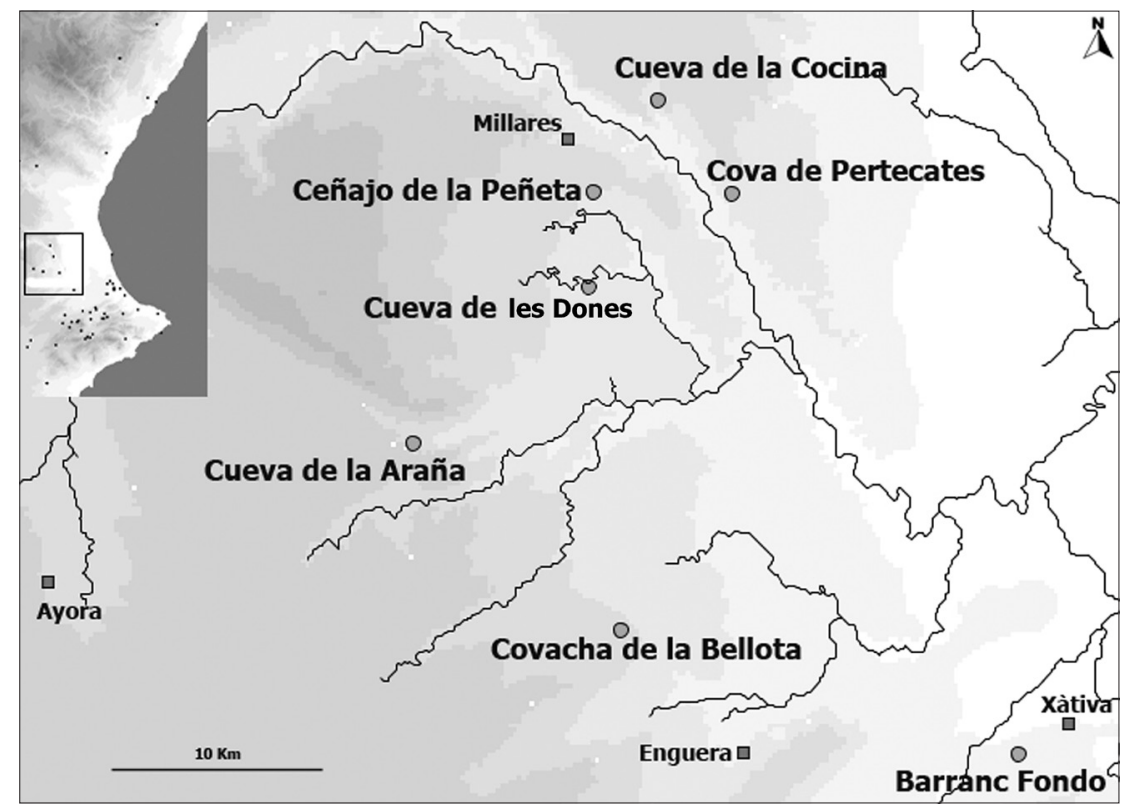

Fig. 25. Jaciments de l'interior de la província de València amb ceràmica cardial.

restes arqueològiques remeten a tradicions culturals del Calcolític final, raó per la que cal suposar que en els voltants de la cova, en cronologies del Bronze antic, poden estar realitzant-se les mateixes activitats que en moments precedents.

Les restes de cronologia ibèrica documentades al Nivell I, queden relacionades amb activitats ramaderes, de descans de viatgers o de cacera. Finalment, les ocupacions del segles XVIII-XIX sí queden relacionades amb activitats ramaderes, doncs existeix un mur de tancament a la cova que interpretem com una preparació de l'entrada per tal d'estabular el ramat, així com nombrosos copròlits als nivells superficials.

\section{CUEVA DE LA DIABLA EN EL CONTEXT DELS GRUPS AGRARIS A AYORA}

L'única intervenció arqueològica sobre restes de cronologia neolítica de la que tenim constància a Ayora es realitzà al jaciment de Puntal del Olmo Seco als anys 80 (Aparicio 1983: 379). Encara que no existeix cap publicació extensa de la intervenció, es fa referència a l'aparició de puntes de fletxa de sílex i ceràmiques fetes a mà, algunes decorades amb cordons impresos.

Donat que la hipòtesi inicial era que estàvem davant d'un jaciment eneolític, es va realitzar una aproximació al context d'arribada de l'agricultura i ramaderia al terme d'Ayora.
Cal admetre la manca de restes que permeten establir la seqüència neolítica a l'interior de la província de València. En algunes coves s'han identificat restes de grups ramaders i/o agricultors del Neolític antic, concretades en la presència de fragments ceràmics amb impressions cardials (Donat Zopo 1969; Fletcher 1971; Fletcher y Aparicio 1970; Fortea 1973; Aparicio 1977; Martí 1978; Fortea et al. 1987; García Robles et al.2005; Inventari de Jaciments de la Generalitat Valenciana) (fig. 25).

Per explicar la presencia d'aquestes restes és possible plantejar una disgregació familiar dintre del grup o comunitat que ocuparia la confluència del Cànyoles i l'Albaida, i una posterior expansió i ocupació de jaciments de l'interior de la província, seguint els mateixos cursos fluvials. La presència d'algunes restes arqueològiques del V mil·lenni cal BC en aquestes mateixes comarques interiors permeten plantejar una continuïtat en l'ocupació del territori. Però estem davant d'una ocupació menys intensa que la que es produí als nuclis postcardials clàssics del $\mathrm{S}$ de la província de València i $\mathrm{N}$ d'Alacant. De fet, no es coneix cap referència a ocupacions del Neolític cardial o post-cardial de la seqüència regional establerta a la Vall d'Ayora.

Poveda (2001) recull les notícies existents, intentant ordenar-les segons els diferents períodes prehistòrics. En quasi tots els casos són troballes descontextualitzades, com els útils de pedra polida de Barranco del Agua i Casa del Baile. Existeix una referència de restes eneolítiques al Castellar de Meca (Poveda 2001), però cal 
Fig. 26. Jaciments del Neolític finalCalcolític en relació amb els assagadors amb grau de "Cañada Real" (segons cartografia temàtica forestal de la Conselleria de Medi Ambient) pròxims a Cueva de la Diabla. 1. Barranco del Agua; 2. Casa del Baile; 3. Castellar de Meca; 4. Abrigo de la Cueva Negra; 5. Puntal del Olmo Seco; 6. Campo Jacinto; 7. La Canaleja; 8. Santic; 9. Coveta Simón; 10. Cebolla; 11. Cueva de la Carrasquilla; 12. Ceñajo de la Peñeta; 13. Cueva del Tortero; 14. Los Pedregales 2; 15. La Fuente Negra; 16. Ereta del Pedregal; 17. Covacha de Saturnino Barrina; 18. La Muela; 19. Camino de la Fuente; 20. El Rincón; 21. El Jesús; 22. Palanqueta; 23. Agres; 24. El Charral; 25. El Calixtro; 26. Camino de la Sierra; 27. Covacha de la Peña del Barreno.

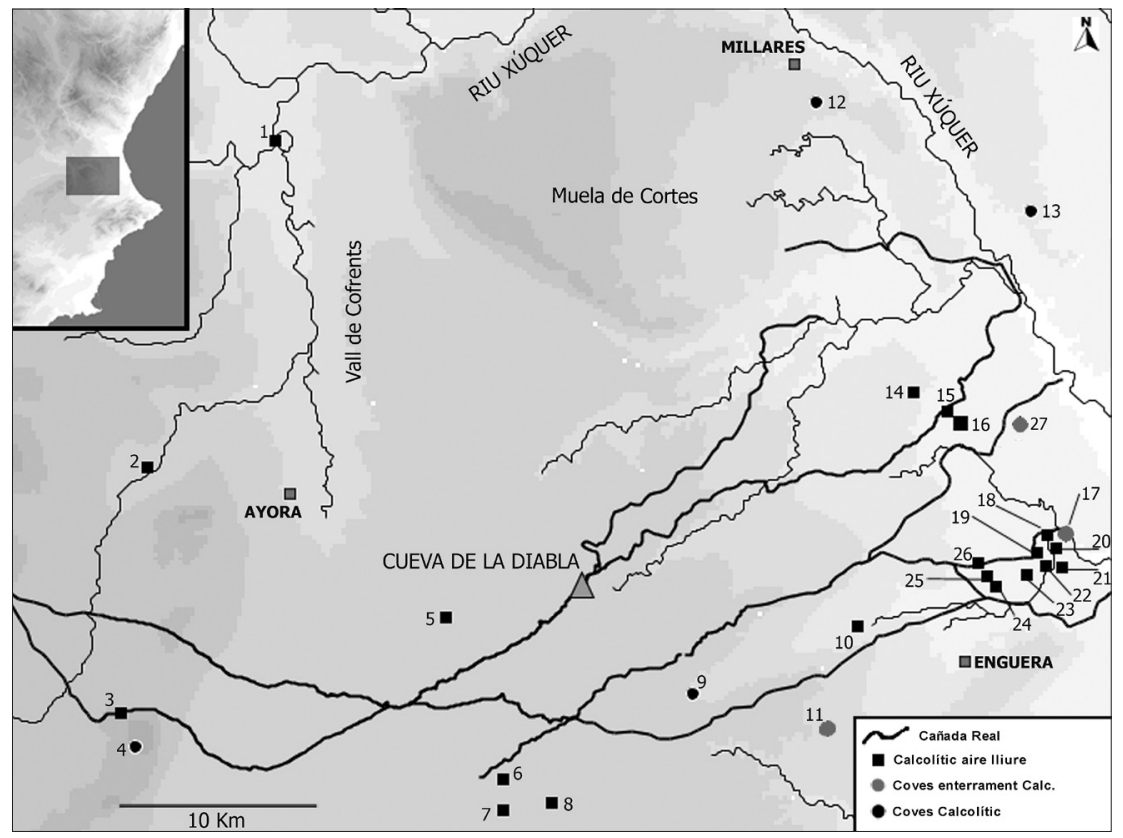

destacar que aquestes podrien ser també de l'Edat del Bronze (Broncano 1986). L'únic cas que presenta alguns dubtes és el de Cueva Negra (Ayora) (Aparicio 1983: 393), però la inexistència de descripcions dels materials i el propi context de la zona, conviden a ubicar-los en moments avançats de la seqüència, al Calcolític o Edat del Bronze.

Aquesta Cueva Negra, no s'ha de confondre amb l'Abric de Cueva Negra o Abrigo de Pedro Mas, que queda ubicat en les immediacions del Castellar de Meca. En ell, Breuil (1915) recollí varias lascas de sílex, un raspador y un trapecio tardenoisense (Fortea 1973: 391), que finalment el propi Fortea descriu com una lámina con truncadura oblícua y silueta de un perfecto trapecio rectángulo, al que le falta el retoque de la truncadura pequeña, és a dir, que pot ubicar-se en el Neolític final (Juan-Cabanilles 2008), en relació amb les ceràmiques realitzades a mà arreplegades a l'abric (Aparicio 1983: 193).

Les dades actuals aconsellen no situar l'arribada de l'agricultura i la ramaderia a Ayora fins el Neolític final o inici del Calcolític, en relació amb un procés general que observem a gran part del País Valencià, lligat amb l'ús de l'arada tirada per animals (Bernabeu 1995; Bernabeu et al. 2006). En aquest context es documenten autèntics llogarets caracteritzats fonamentalment per grans conjunts de sitges per a l'emmagatzematge del gra, en alguns casos amb capacitats molt destacades. Paral-lelament trobem un augment del registre funerari (Soler 2002) que es lliga directament amb aquests llogarets estables (Bernabeu i Pascual 1998). Tots aquests factors aniran afavorint una ocupació de territoris com la que ens ocupa, qüestió que es constata amb un augment del nombre de jaciments documentats (fig. 26).

Les ocupacions inicials de Cueva de la Diabla, deuen de ser enteses dintre d'aquesta dinàmica d'expansió demogràfica i l'establiment de poblats, necròpolis o camins, així com l'aprofitament total d'un medi escassament antropitzat. La importància de la cacera en les seues ocupacions, la interpretem dintre d'aquest aprofitament de recursos que ofereixen els territoris de la Canal de Navarrés i la Vall d'Ayora per l'escassa antropització del medi immediat (Martí i Juan-Cabanilles 2002). És una característica que no es presenta com a única, documentant-se de forma general en jaciments calcolítics ubicats fora del nucli cardial de neolitització, tot i que amb una clara vocació econòmica agrícola i ramadera, com Ereta del Pedregal (Pérez Ripoll 1990), Fuente Flores (Juan-Cabanilles i Martínez Valle 1988) o Fuente de Isso (Hellín, Albacete) (García Atiénzar 2010), que perdura al Calcolític campaniforme i Bronze antic. En aquestos casos, cal matisar que l'abundància d'herbívors els convertiria en un competidor que provocaria destrosses als camps de conreu, per la qual cosa augmentaria la cacera sistemàtica, com s'ha pogut comprovar en moments posteriors (Iborra 2004: 367). 
Pablo García Borja, Yolanda Carrión Marco, José Enrique lópez Peris, Juan Vicente Morales Pérez, Salvador Pardo Gordó, Felip Pérez i Ferrer, Guillem Pérez Jordà, Dídac Roman Monroig, Pablo Sañudo Die, Carlos Verdasco Cebrián

\section{CONCLUSIONS}

Els sondejos arqueològics realitzats a Cueva de la Diabla ens han permès identificar diferents moments d'ús de la mateixa. La primera queda establerta en moments avançats del Calcolític campaniforme-Bronze antic, moment en el que comença a conformar-se el Nivell II. Al Nivell I hem documentat materials arqueològics que remeten a un moment d'ocupació ibèric, altre modern, i altre contemporani.

La funcionalitat de la cova al llarg dels diferents períodes d'ocupació fins l'actualitat ha estat variada, essent la cacera l'activitat que millor ha quedat documentada per a cronologies prehistòriques. La presència sota la cova de la "Cañada Real de San Benito" que comunica la Canal de Navarrés amb Almansa queda relacionada amb la seua ocupació inicial com a lloc de descans de viatgers o caçadors, no documentant-se un ús sistemàtic com a lloc d'habitació o per estabular ramat en moments prehistòrics. A l'època ibèrica, moderna i contemporània, la cova sembla que hauria estat utilitzada com a lloc de parada o per estabular el bestiar.

L'ocupació prehistòrica de la cova, queda relacionada amb una tardana implantació de l'agricultura i ramaderia al terme d'Ayora i voltants, hipòtesis que també s'ha plantejat a la veïna província d'Albacete (García Atienzar 2010). L'existència de nuclis calcolítics consolidats seria la que provocaria l'ocupació de la cova, en relació amb activitats de cacera fora del territori immediat al llogaret, o amb l'establiment de veritables vies de comunicació.

Pablo García Borja Arqueòleg n $\mathrm{n}^{\circ} 15.960$ del Col·legi Oficial de Doctors Llicenciats en Filosofia i Lletres i en Ciències de València paucanals@hotmail.com

Yolanda CARrión Marco Juan Vicente Morales Pérez Salvador Pardo Gordó DíDAC ROMAN MONROIG Departament de Prehistòria i d'Arqueologia Universitat de València yolanda.carrion@uv.es juanvimorales@gmail.com salvador.pardo@uv.es didac.roman@uv.es

FELIP PÉREZ I FERRER

Arqueòleg n ${ }^{\circ} 16.181$ del Col·legi Oficial de Doctors i Llicenciats en Filosofia i Lletres i en Ciències de València feperezfer@gmail.com
GuILlem PÉREZ JoRdÀ G.I. Arqueobotánica. IH. CCHS. CSIC guillem.perez@uv.es

José EnRiQue López Peris Pablo Sañudo Die Carlos Verdasco Cebrián Estudios de Afectación Patrimonial, S.L. info@estudiospatrimoniales.es

\section{AGRAÏMENTS}

Les datacions presentades han estat realitzades en el marc dels projectes "Origins and Spread of Agriculture in the western Mediterranean region" (ERC-2008-AdG 230561) i “Amplitud geográfica y ecológica de Rosmarinus officinalis: múltiples aproximaciones a las posibles causas" (CGL2009-07262). L'anàlisis antracològica s'integra en el projecte "Los bioindicadores del cambio climático: caracterización de los paisajes mediterráneos en el tránsito Pleistoceno-Holoceno a partir de la madera carbonizada" (GV/2011/020). Agrair a Joaquim Juan Cabanilles els seus consells i correccions.

\section{BIBLIOGRAFIA}

APARICIO, J. (1977): Trabajos de Prehistoria: I-Hallazgo en la dehesa del Pilar Bajo (Setenil, Cádiz). II- La Cova del Barranc Fondo (Játiva, Valencia), XIX Congreso Nacional de Arqueología, Saragossa.

APARICIO, J.; SAN VALERO, J.; MARTÍNEZ, J.V.; MOROTE, G.; MARTÍNEZ, J.M.; LATORRE, F.; CISNEROS, F.; LÓPEZ, P.; SÁNCHIS J.R.; MARTÍNEZ J.S.; MARTÍNEZ, F.; ESTEVE C. (1983): Actividades Arqueológicas desde 19791982, Serie Arqueológica Varia II, Departamento de Historia Antigua de la Universitat de València, 201-503.

BERNABEU, J. (1984): El Vaso Campaniforme en el País Valenciano, Serie de Trabajos Varios del S.I.P., 80. València.

BERNABEU, J. (1989): La tradición cultural de las cerámicas impresas en la zona oriental de la península Ibérica, Serie de Trabajos Varios del S.I.P. 86, València.

BERNABEU, J. (dir.) (1993): El tercer milenio a.C. en el País Valenciano. Los poblados de Jovades (Cocentaina, Alacant) y Arenal de la Costa (Ontinyent, Valencia), SAGVNTVML-PLAV 26, 9-179.

BERNABEU, J. (1995): Origen y Consolidación de las sociedades agrícolas. El País Valenciano entre el Neolítico y la Edad del Bronce, Actes de les Jornades d'Arqueologia a Alfàs del Pi (27-29 de Gener de 1994), Generalitat Valenciana, 37-60.

BERNABEU, J.; GUITART, I. (1993): La industria cerámica, En J. Bernabeu (dir.), El III milenio a.C. en el País valenciano. Los poblados de Jovades (Cocentaina) y Arenal de la Costa (Ontinyent), SAGVNTVM-PLAV 26, 47-66. 
BERNABEU, J.; PASCUAL, J. LL.; OROZCO, T.; BADAL, T. FUMANAL, M.P.; GARCÍA, O. (1994): Niuet (l'Alqueria D’Asnar). Poblado del III Milenio a.C, Recerques del Museu d'Alcoi 3, 9-74.

BERNABEU, J.; OROZCO, T., (1994): La Cerámica, En J. Bernabeu et al., Niuet (l'Alqueria D'Asnar). Poblado del III Milenio a.C, Recerques del Museo d'Alcoi 3, 28-41.

BERNABEU, J.; PASCUAL BENITO J.L. (1998): L'expansió de l'agricultura. La Vall del riu Alcoi fa 5000 anys, València, Museu de Prehistòria-Diputació de València.

BERNABEU, J.; MOLINA, LL.; DIEZ, A.; OROZCO, T. (2006): Inequalities and power. Three millenia of Prehistory in Mediterranean Spain (5600-2000 cal BC), Social Inequality in Iberian Late Prehistory (P. Díaz-del-Río, L. García Sanjuán, eds.), Oxford, 97-116.

BERNABEU, J.; MOLINA, LL.; GUITART, I.; GARCÍA BORJA, P. (2009): La cerámica prehistórica: metodología de análisis e inventario de los materiales, La Cova de les Cendres (Moraira-Teulada), CD adjunto (J. Bernabeu, LL. Molina eds.), Alacant, 50-178.

BLANCO, J. C. (1998): Mamíferos de España, Barcelona.

BREUIL, H. (1915): Les peintures rupestres d'Espagne. VII. Nouvelles roches peintes de la région d'Alpera (Albacete), L'Anthropologie 26, 330-331.

BRONCANO, S. (1986): El Castellar de Meca. Ayora, Excavaciones Arqueológicas en España 147.

CARRIÓN, J.S.; NAVARRO, C.; NAVARRO, J.; MUNUERA, M. (2000): The distribution of cluster pine (Pinus pinaster) in Spain as derived from palaeoecological data: relationships with phytosociological classification, The Holocene, 10 (2), 243-252.

DOI: http://dx.doi.org/10.1191/095968300676937462

COSTA, M. (1982): Pisos bioclimáticos y series de vegetación en el área valenciana, Cuadernos de Geografía 31, 129-142.

COSTA, M.; PERIS, J.B. (1984): Aportación al conocimiento fitosociológico del Boquerón y Palomera (Valencia-Albacete): los matorrales, Lazaroa 6, 81-103.

DONAT ZOPO, J. (1969): Cova de las Donas, Millares, Valencia. Institució Alfons el Magnànim, València.

DUPRÉ, M. (1988): Palinología y Paleoambiente. Nuevos datos españoles. Referencias, Serie de Trabajos Varios del S.I.P. 84 , València.

FIGUEIRAL, I. (1995): Charcoal analysis and the history of Pinus pinaster (cluster pine) in Portugal, Review of Palaeobotany and Palynology 89, 441-454. DOI: http://dx.doi.org/10.1016/0034-6667(95)00013-3

FLETCHER, D.; APARICIO, J. (1970): Exploraciones arqueológicas en el barranco del Lobo (Chella, València), XI Congreso Nacional de Arqueología (Mérida, 1968), 265-270.

FLETCHER, D. (1971): La labor del Servicio de Investigación Prehistórica y su museo en el pasado año 1969. València.

FORTEA, F.J. (1973): Los complejos microlaminares y geométricos del Epipaleolítico mediterráneo peninsular, Salamanca.
FORTEA, F.J.; MARTÍ, B.; FUMANAL, P.; DUPRÉ, M.; PÉREZ RIPOLL, M. (1987): Epipaleolítico y Neolitización en la zona oriental de la Península Ibérica, Premières communautés paysannes en Méditerranée occidental. Actes du Colloque International du CNRS (Montpellier, 1983) (J. Guilaine, J. Courtin, J.L. Roudil, J.L. Vernet, dirs.), Paris, 599-606.

GARCÍA ATIENZAR, G. (2010): El yacimiento de Fuente Isso (Hellín) y el poblamiento Neolítico en la provincia de Albacete, Albacete.

GARCÍA BORJA, P. (2004): La Cerámica, En M. Gómez Puche et al., El yacimiento de Colata (Montaverner Valencia) y los poblados de silos del IV milenio en las comarcas centromeridionales del País Valenciano, Recerques del Museu d'Alcoi 13, 53-128.

GARCÍA BORJA, P.; CORTELL; E., PARDO, S.; PÉREZ JORDÀ, G. (2011): Las cerámicas de la Cova de l'Or (Beniarrés, Alacant). Tipología y decoración de las colecciones del Museu d'Alcoi, Recerques del Museu d'Alcoi 19, 71-136.

GARCÍA ROBLES, M.R.; GARCÍA PUCHOL, O.; MOLINA, LL. (2005): La Neolitización de las comarcas interiores valencianas y la cronología del arte levantino: un nuevo marco para un viejo debate, III Congreso del Neolítico en la Península Ibérica (P. Arias, R. Ontañón, C. García-Monco, eds.), Santander, 793-802.

GÓMEZ PUCHE, M.; DIEZ, A.; VERDASCO, C.; GARCÍA BORJA, P.; McCLURE, S.B.; LÓPEZ GILA, M.D.; GARCÍA PUCHOL, O.; OROZCO, T.; PASCUAL BENITO, J.LL.; CARRIÓN MARCO, Y.; PÉREZ JORDÁ, G. (2004): El yacimiento de Colata (Montaverner Valencia) y los poblados de silos del IV milenio en las comarcas centro-meridionales del País Valenciano, Recerques del Museu d'Alcoi 13, 53-128.

HARRIS E.C. (1989): Principles of archaeological stratigraphy, London.

IBORRA M.P. (2004): La ganadería y la caza desde el Bronce Final hasta el Ibérico Final en el territorio valenciano, Serie de Trabajos Varios del S.I.P. 103, València.

JOVER F.J. (2008): Caracterización de los procesos de producción lítica durante la Edad del Bronce en el levante de la Península ibérica, Lucentum XXVII, 43-67.

JUAN-CABANILLES, J. (2008): El utillaje de la piedra tallada en la Prehistoria reciente valenciana. Aspectos tipológicos, estilísticos y evolutivos, Serie de Trabajos Varios del S.I.P. 109 , València.

JUAN-CABANILLES, J.; MARTÍNEZ VALLE, R. (1988): Fuente Flores (Requena, Valencia). Nuevos datos sobre el poblamiento y la economía del neo-eneolítico valenciano, Archivo de Prehistoria Levantina, XVIII, 181-231.

LANDT, M.J. (2004): Investigations of human gnawing on small mammal bones: among contemporary Bofi foragers of the Central African Republic, Departament of Anthropology. Washington State University. 
Pablo García Borja, Yolanda Carrión Marco, José Enrique López Peris, Juan Vicente Morales Pérez, Salvador Pardo Gordó, Felip Pérez i Ferrer, Guillem Pérez Jordà, Dídac Roman Monroig, Pablo Sañudo Die, Carlos Verdasco Cebrián

LANDT, M.J. (2007): Tooth marks and human consumption: ethnoarchaeological mastication research among foragers of the Central African Republic, Journal of Archaeological Science 34, 1629-1640.

DOI: http://dx.doi.org/10.1016/j.jas.2006.12.001

LÓPEZ GILA, M.D. (2004): Los restos faunísticos, En M. Gómez Puche et al., El yacimiento de Colata (Montaverner Valencia) y los poblados de silos del IV milenio en las comarcas centro-meridionales del País Valenciano, Recerques del Museu d'Alcoi 13, 53-128.

MARTÍ OLIVER, B., (1978): El Neolítico Valenciano, Tesis doctoral Inédita.

MARTÍ OLIVER, B. (1983): La Muntanya Assolada (Alzira, València), Lucentum II, 43-67.

MARTÍ OLIVER B.; GIL SANCHO J. (1978): Perlas de Aletas y Glóbulos del Cau Rabosser (Carcaixent, València) (Algunas consideraciones sobre el Eneolítico valenciano), Archivo de Prehistoria Levantina XV, 47-68.

MARTI OLIVER, B.; JUAN-CABANILLES, J. 2002: La decoració de les ceràmiques neolítiques i la seua relació amb les pintures rupestres dels abrics de la Sarga, La Sarga. Arte rupestre y territorio (M.S. Hernández, J.M. Segura, coords.), Alcoi, 147-170.

MARTÍNEZ VALLE, R. (1993): La fauna de vertebrados, en J. Bernabeu (dir.), El III milenio AC en el País Valenciano. Los poblados de Jovades (Cocentaina, Alacant) y Arenal de la Costa (Ontinyent, València), SAGVNTVMPLAV 26, 123-151.

MATEUS, J.E.; QUEIROZ, P.F. (1993): Os estudos de vegetação quaternária em Portugal; contextos, balanço de resultados, perspectivas, O Quaternário em Portugal, Balanço e Perspectivas, Lisboa, 105-131.

PASCUAL BENITO, J.LL. (1988-89): Les Coves sepulcrals de l'Alberri (Cocentaina), SAGVNTVM-PLAV 21, 110-167.

PASCUAL BENEYTO, J.; RIBERA I GOMES, A. (2004): El Molí Roig. Un jaciment del III mil·leni a Banyeres de Mariola (1'Alcoià), Recerques del Museu d'Alcoi 13, 129-148.

PÉREZ JORDÀ, G.; CARRIÓN MARCO, Y. (2011): Los recursos vegetales, La Vital. Vida y muerte en la desembocadura del Serpis durante el III y el I milenio a.C. (G. Pérez Jordà, J. Bernabeu, Y. Carrión Marco, O. García Puchol, LL. Molina, M. Gómez Puche, eds.), Trabajos Varios del S.I.P. 113, Valencia, 97-103.

PÉREZ RIPOLL, M. (1990): La ganadería y la caza en la Ereta del Pedregal (Navarrés, Valencia), Archivo de Prehistoria Levantina XX, 223-253.
PÉREZ RIPOLL, M. (1999): La explotación ganadera durante el III milenio a.C. en la Península Ibérica, Actes del II Congrés del Neolític a la Península Ibérica (J. Bernabeu, T. Orozco, eds.), Valencia, 95-103.

PERIS, J.B.; SANCHÍS, E. (1996): Dinamismo de la vegetación y los suelos de las Sierras del Boquerón y Palomera (Valencia y Albacete, España), Al-Basit: Revista de Estudios Albacetenses 38, 31-41.

POVEDA, J.V. (2001): Historia del Valle de Ayora-Cofrentes. Desde la Prehistoria hasta la expulsión de los Moriscos (1609), Mancomonudidad del Valle de Ayora-Cofrentes.

RAMIL-REGO, P. (1992): La vegetación cuaternaria de las Sierras Septentrinales de Lugo a través del análisis polínico, Tesis doctoral, Universidade de Santiago de Conpostela.

REILLE, M.; LOWE, J.J. (1993): A re-evaluation of the vegetation history of the eastern Pyrenees (France) from the end of the last glacial to the present, Quaternary Science Reviews 12, 47-77.

DOI: http://dx.doi.org/10.1016/0277-3791(93)90048-Q

REIMER, P.J.; BAILLIE, M.G.L.; BARD, E.; BAYLISS, A.; BECK, J.W.; BLACKWELL, P.G.; BRONK RAMSEY, C.; BUCK, C.E.; BURR, G.S.; EDWARDS, R.L.; FRIEDRICH, M.; GROOTES, P.M.; GUILDERSON, T.P.; HAJDAS, I.; HEATON, T.J.; HOGG, A.G.; HUGHEN, K.A.; KAISER, K.F.; KROMER, B.; MCCORMAC, F.G.; MANNING, S.W.; REIMER, R.W.; RICHARDS, D.A.; SOUTHON, J.R.; TALAMO, S.; TURNEY C.S.M.; VAN DER PLICHT, J.; WEYHENMEYER C.E. (2009): INTCAL09 and MARINE09 radiocarbon age calibration curves, 0-50,000 years cCal BP, Radiocarbon 51, 1111-1150.

SANCHIS SERRA, A. (2000): Los restos de Oryctolagus cuniculus en la tafocenosis de Bubo bubo y Vulpes vulpes y su aplicación a la caracterización del registro faunístico arqueológico, SAGVNTVM-PLAV 32, 31-50.

SANCHIS, A.; MORALES, J.V.; PÉREZ RIPOLL, M. (e.p.) Creación de un referente experimental para el estudio de las alteraciones causadas por dientes humanos sobre huesos de conejo, II Congreso Internacional de Arqueología Experimental 26, 27, 28 de noviembre 2008, Ronda (Málaga, Spain).

SOLER, J.A. (2002): Cuevas de inhumación múltiple en la comunidad Valenciana, Madrid-Alicante.

TAPIAS, R.; GIL, L.; FUENTES-UTRILLA, P.; PARDOS, J.A. (2001): Canopy seed Banks in Mediterranean pines of south-eastern Spain: a comparison between Pinus halepensis Mill., P. pinaster Ait., P. nigra Arn. and P. pinea L., Journal of Ecology 89, 629-638.

DOI: http://dx.doi.org/10.1046/j.1365-2745.2001.00575.x 